Review

\title{
Something about Robots Today
}

\author{
${ }^{1}$ Nicolae Petrescu, ${ }^{2}$ Raffaella Aversa, \\ ${ }^{2}$ Antonio Apicella and ${ }^{3}$ Florian Ion Tiberiu Petrescu \\ ${ }^{I}$ Bucharest University, Bucharest, (CE), Romania \\ ${ }^{2}$ Department of Architecture and Industrial Design, Advanced Material Lab, \\ Second University of Naples, 81031 Aversa (CE), Italy \\ ${ }^{3}$ ARoTMM-IFToMM, Bucharest Polytechnic University, Bucharest, (CE), Romania
}

\section{Article history}

Received: 01-06-2018

Revised: 04-06-2018

Accepted: 11-06-2018

Corresponding Author:

Florian Ion Tiberiu Petrescu

ARoTMM-IFToMM, Bucharest

Polytechnic University,

Bucharest, (CE), Romania

E-mail: scipub02@gmail.com
Abstract: Today, robots are increasingly present in the machine building industry, sometimes even in some sections to replace workers altogether, due to the high quality of their work, repetitive, without stopping or pausing, without any manufacturing and assembly scuffs. Additionally, robots do not get sick, do not require medical leave or rest, work faster and better than humans and also support toxic environments from dyers, general assemblies, etc. Generally, robots have increased the quality and productivity of work and have not even created a union to defend their claims, demanding increased wages for them and larger holidays. Interestingly, a robot is working without a break, but without salary, without breaks, without complaining about working conditions in the plant. It has come to the effect that the big car manufacturers and even others, have entire sections in which only robots work. They do not have to worry about each other, do not quarrel, do not complain, do not cry, do not ask for the salary, do not require leave, they do not want free days and can work with high returns and Saturday and Sunday, if necessary on three shifts without a break. The importance of implementing robots can no longer be challenged. They have so increased the quality of work and the production of an enterprise that they can no longer give up their help. Workers have reclassified themselves and work only in more friendly workplaces, or in other workplaces, such as supermarkets, in better conditions, with higher wages, with several days off and they are also pleased and all this is due to production and additional gains from higher sales due to the robot work in large factories. We can clearly state that robots have improved our lives considerably. Thanks to them, a new free day was introduced for almost all working people, Friday, in addition to Saturday and we may soon be able to introduce another free day, but we have to choose whether it is Monday or Thursday. People, in the beginning, were taught by the trade union bosses to chase and sabotage the robots, to ruin them and not to accept them. Today things are clear and the robots work quietly in the big companies and factories for the sake of everyone, so now we can all accept the silence of the automation, the robotics, the electronics, without letting us be fooled by the union leaders, who slowly slow down and they will calm down. Robots can work on three shifts, that is, permanently, but not by shifting them like people did, but always remaining the same robots deployed in operation, nonstop, for days, without breaks, without rest, without problems. If we like it or not like, robots have already stolen all our hard works places.

Keywords: Robot Implementation, Social Issues, Anthropomorphic Mechatronic Systems, Robots, Mechatronics, Kinetostatics, Dynamics, Dynamic Kinematics 


\section{Introduction}

Today, robots are increasingly present in the machine building industry, sometimes even in some sections to replace workers altogether, due to the high quality of their work, repetitive, without stopping or pausing, without any manufacturing and assembly scuffs.

Additionally, robots do not get sick, do not require medical leave or rest, work faster and better than humans and also support toxic environments from dyers, general assemblies, etc.

Generally, robots have increased the quality and productivity of work and have not even created a union to defend their claims, demanding increased wages for them and larger holidays. Interestingly, a robot is working without a break, but without salary, without breaks, without complaining about working conditions in the plant.

Robots can work on three shifts, that is, permanently, but not by shifting them like people did, but always remaining the same robots deployed in operation, nonstop, for days, without breaks, without rest, without problems.

It has come to the effect that the big car manufacturers and even others, have entire sections in which only robots work. They do not have to worry about each other, do not quarrel, do not complain, do not cry, do not ask for the salary, do not require leave, they do not want free days and can work with high returns and Saturday and Sunday, if necessary on three shifts without a break.

The importance of implementing robots can no longer be challenged. They have so increased the quality of work and the production of an enterprise that they can no longer give up their help. Workers have reclassified themselves and work only in more friendly workplaces, or in other workplaces, such as supermarkets, in better conditions, with higher wages, with several days off and they are also pleased and all this is due to production and additional gains from higher sales due to the robot work in large factories.

We can clearly state that robots have improved our lives considerably. Thanks to them, a new free day was introduced for almost all working people, Friday, in addition to Saturday and we may soon be able to introduce another free day, but we have to choose whether it is Monday or Thursday.

People, in the beginning, were taught by the trade union bosses to chase and sabotage the robots, to ruin them and not to accept them. Today things are clear and the robots work quietly in the big companies and factories for the sake of everyone, so now we can all accept the silence of the automation, the robotics, the electronics, without letting us be fooled by the union leaders, who slowly slow down and they will calm down.

If we like it or not like, robots have already stolen all our hard works places.

Anthropomorphic robots are, as I have already said, in most of the most widespread and widely used works worldwide today, due to their ability to adapt quickly to forced work, working without breaks or breaks $24 \mathrm{~h}$ a day, without unpaid leave without asking for food, water, air, or salary. Anthropomorphic robots are supple, elegant, easy to configure and adapted to almost any required location, being the most flexible, more useful, more penetrating, easy to deploy and maintain. For the first time, these robots have asserted themselves in the automotive industry and especially in the automotive industry, today they have penetrated almost all industrial fields, being easily adaptable, flexible, dynamic, resilient, cheaper than other models, occupying a volume smaller but with a major working space. They can also work in toxic or dangerous environments, so used in dyeing, chemical cleaners, in chemical or nuclear environments, where they handle explosive objects, or in military missions to land or sea mines, even if they were banned to use, because there are still countries around the globe that use them, such as Afghanistan.

The most used today's industrial robots, is built. The importance of the study of anthropomorphic robots has also been signaled, being today the most widespread robots worldwide, due to its simple design, construction, implementation, operation and maintenance. In addition, anthromomorphic systems are simpler from a technological and cheaper point of view, performing a continuous, demanding, repetitive work without any major maintenance problems. The basic module of these robots was also presented geometrically, cinematically, of the forces, of its total static balancing and of the forces that arise within or after balancing. In the present paper we want to highlight the dynamics of the already statically balanced total module. It has been presented in other works and studied matrix spatially, or more simply in a plan, but in this case, it is necessary to move from the working plane to the real space, or vice versa, passage that we will present in this study. In the basic plan module already presented in other geometric and cinematic works, we want to highlight some dynamic features such as static balancing, total balancing and determination of the strength of the module after balancing. Through a total static balancing, balancing the gravitational forces and moments generated by the forces of gravity is achieved, balancing the forces of inertia and the moments (couples) generated by the presence of inertial forces (not to be confused with the inertial moments of the mechanism, which appear separately from the other forces, being part of the inertial torsion of a mechanism and depending on both the inertial masses of the mechanism and its angular accelerations. Balancing the mechanism can be done through various methods. Partial balancing is achieved almost in all cases where the actuators (electric drive motors) are fitted with a mechanical reduction, a mechanical transmission, a sprocket, spiral gear, spool screw type. This results in a "forced" drive balancing from the transmission, which 
makes the operation of the assembly to be correct but rigid and with mechanical shocks. Such balancing is not possible when the actuators directly actuate the elements of the kinematic chain without using mechanical reducers (Antonescu and Petrescu, 1985; 1989; Antonescu et al., 1985a; 1985b; 1986; 1987; 1988; 1994; 1997; 2000a; 2000b; 2001; Aversa et al., 2017a; 2017b; 2017c; 2017d; 2017e; 2016a; 2016b; 2016c; 2016d; 2016e; 2016f; 2016g; 2016h; 2016i; 2016j; 2016k; 20161; 2016m; 2016n; 2016o; Berto et al., 2016a; 2016b; 2016c; 2016d; Cao et al., 2013; Dong et al., 2013; Comanescu, 2010; Franklin, 1930; He et al., 2013; Lee, 2013; Lin et al., 2013; Liu et al., 2013; Mirsayar et al., 2017; Padula and Perdereau, 2013; Perumaal and Jawahar, 2013; Petrescu, 2011; 2015a; 2015b; Petrescu and Petrescu, 1995a; 1995b; 1997a; 1997b; 1997c; 2000a; 2000b; 2002a; 2002b; 2003; 2005a; 2005b; 2005c; 2005d; 2005e; 2011; 2012a; 2012b; 2013a; 2013b; 2016a; 2016b; 2016c; Petrescu et al., 2009; 2016; $2017 \mathrm{a} ; 2017 \mathrm{~b} ; 2017 \mathrm{c} ; 2017 \mathrm{~d} ; 2017 \mathrm{e} ; 2017 \mathrm{f} ; 2017 \mathrm{~g}$; 2017h; 2017i; 2017j; 2017k; 2017l; 2017m; 2017n; 2017o; 2017p; 2017q; 2017r; 2017s; 2017t; 2017u; $2017 \mathrm{v} ; 2017 \mathrm{w} ; 2017 \mathrm{x} ; 2017 \mathrm{y} ; 2017 \mathrm{z} ; 2017 \mathrm{aa} ; 2017 \mathrm{ab}$; 2017ac; 2017ad; 2017ae; 2018 a-n).

\section{Materials and Methods}

The Mitsubishi Mechatronic Stand, from the JC104 Mechatronics Room, Theory of Mechanisms and Robots, Engineering Department at the Polytechnic University of Bucharest, can help researchers and students to determine in real time various kinematic and dynamic parameters (Fig. 1).

Mechatronic positioning system consists of:

\section{Position controller}

The servoamplifier adapted to the position controller Stepper motor

Actuator

Hardware and interconnect software

Position controller:

Positioning modules are chain pulse output units, which offer the controller the ability to position stepper motors and actuators via the drive unit.

Number of control axes: 2 independent or simultaneous axes;

Program memory: 7.8 Kpad with included RAM, recovery battery and optional EEPROM;

Positioning:

Method: Absolute or incremental data;

Units: $\mathrm{mm}$, inch, degrees and pulse;

Counting resolution: 31 bit + signal, -2147483648 to 2147483647;

Maximum Counting Frequency: $200 \mathrm{kHz}$;

Speed: $1,530,000 \mathrm{~mm} / \mathrm{min}$;

I/O points: 8 ;
Power supply: 24 V DC (-15\% to $+10 \%)$;

Power consumed: 10 ;

Weight: $0.4 \mathrm{~kg}$;

Dimension (mm): $86 \times 90 \times 87$

Servoamplifier adapted to the position controller (Fig. 2):

They must provide facilities in making loose and open loops.

The continuous torque - with feedback from the encoder and speeds from $4500 \mathrm{rpm}$, up to $300 \%$ of torque is made from 0 to the maximum speed;

High dynamic performance - in applications requiring short duty cycles, eliminating operating problems and increasing output and reducing standby time;

Adaptive real-time tuning - automatic settings remove closed-loop system malfunctions, making it fast and easy to install;

Other features to include:

Simple test operations providing standard functions from the keys to the unit;

Ultra-low inertia motors on the HC-PQ range for required cycle demands and fast dynamic response;

Extensive protective functions to prevent engine and amplifier damage;

Overall standards approved by the EC and the UL;

Serial communication interface option with Windows-based software that allows advanced communications and diagnostic tools.

All can be seen and monitored in real-time on the device's large screen (Fig. 3), being completely separate from the main monitor.

\section{Stepper Motor}

Transport units, handling devices and variable-stroke processing lines are supported by simple programs for different positioning applications (Fig. 4).

The stepper motor must have:

5 walking modes (without brake);

Driving screw: $\varnothing 8 \mathrm{~mm}$ slip screw, ball screw $\square 8 \mathrm{~mm}$;

Race (mm): 6-12; 2-5;

Repeatability of positioning: $\pm 0.05 \mathrm{~mm} ; \pm 0.03 \mathrm{~mm}$;

Speed (mm / s): 6-10; 12-200; 2-30; 5-80;

Horizontal workload (kg): 3 (2); 2 (2); 3 (2); 3 (2);

Guiding type: direct drive guidance;

Temperature range for operation (0C): 5-40;

Applicable driver

CE marker accessories;

Actuator adapted to the position controller, stepper motor and servo amplifier, shown above. By attaching a module to the base unit of the controller, the connection interface (adapter) is required. 


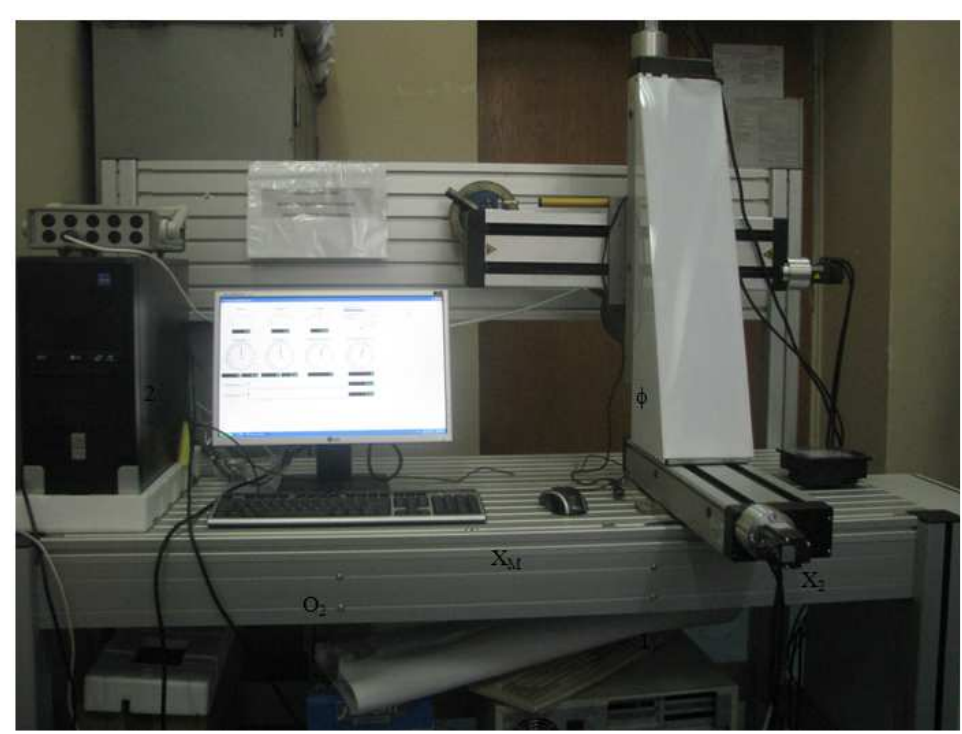

Fig. 1: Mechatronic positioning system - (Command and control system)

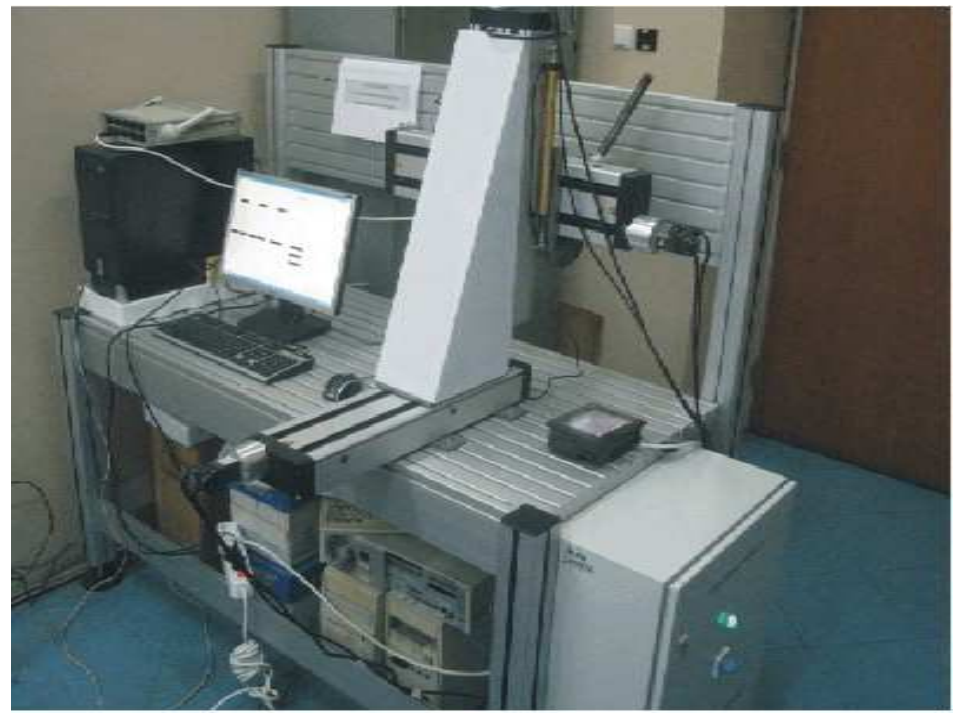

Fig. 2: Command and control system: Servo amplifier adapted to the position controller

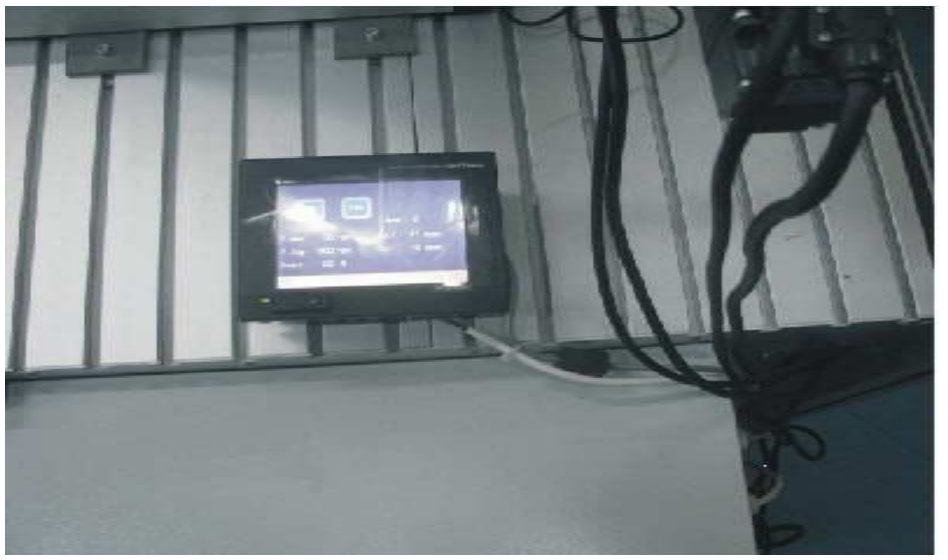

Fig. 3: All can be seen and monitored in real-time on the device's large screen 


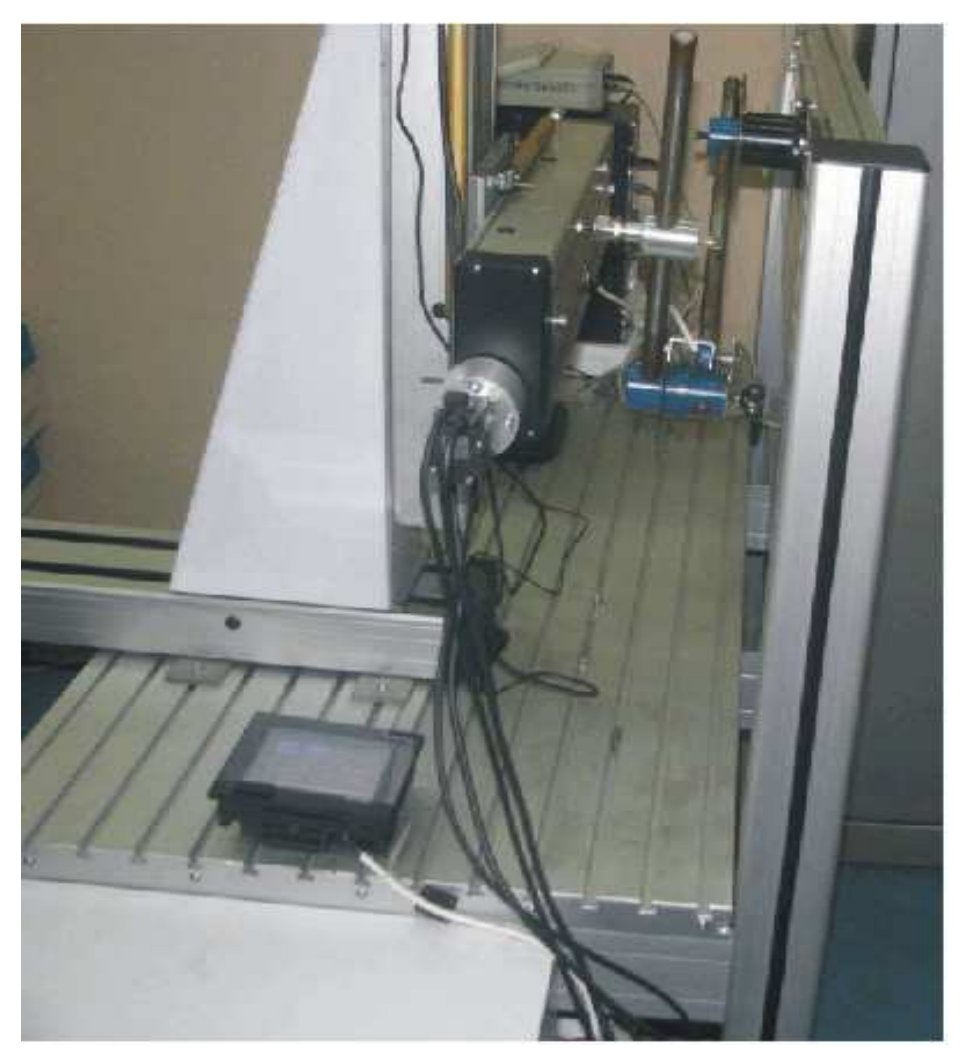

Fig. 4: Transport units, handling devices and variable-stroke processing lines are supported by simple programs for different positioning applications

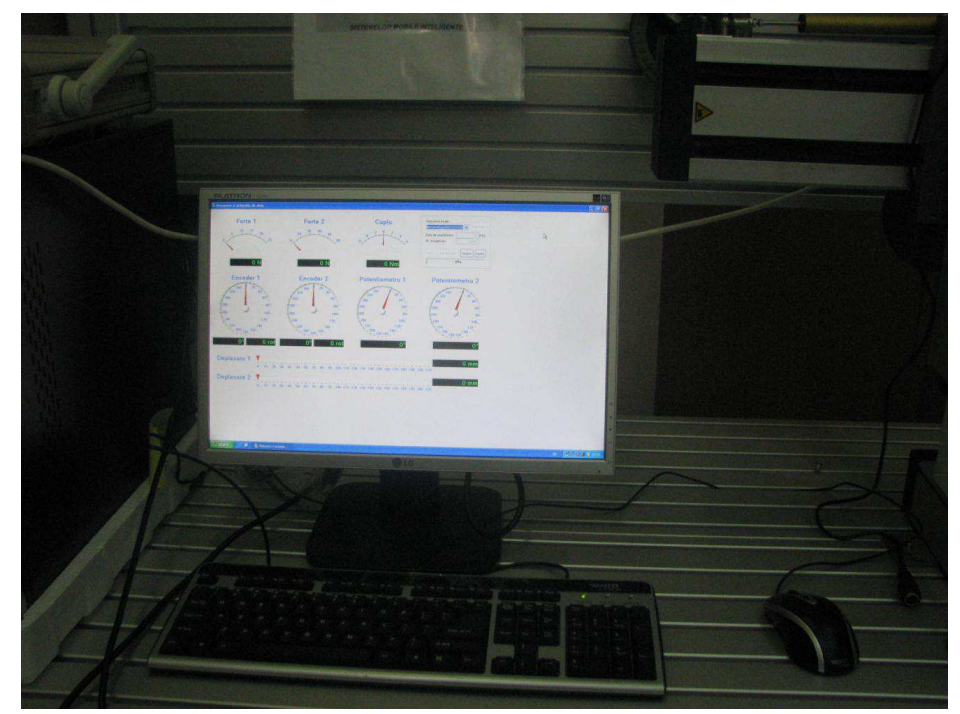

Fig. 5: Modular mechatronic system for didactic laboratory - (Control system)

Interconnect hardware and software components adapted to the position controller, stepper motor and servo amplifier listed above.

Friendly programming software allows even beginners to perform complicated positioning tasks in an easy way.

\section{Modular Mechatronic System for Didactic Laboratory - (Control System)}

The modular concept is ideal for initial training and continuous improvement in mechatronics. Functional modules must be adapted to the various automated 
technologies (Fig. 5). The modules are placed on an expandable mechatronic system, so it can be expanded by creating new projects and making some ideas worthwhile.

The complete station includes conveyor station, processing station, storage station, PLC, pressure source, hardware and interconnection software.

The conveyor station contains the conveyor module, the test unit module with 4 test positions, the separation modules.

The processing station comprises the handling module, the pneumatic pressing module, the operating unit.
The storage station comprises the horizontal axis module, the vertical axis module, the storage module, the maintenance module.

Industrial robots have penetrated all important areas (Fig. 6 and 7).

The Nao robot (Fig. 8) helps students and researchers create different algorithms capable of developing the robot's robot as diverse as possible, but also the possibility of making previously thought-out programs that enable him to perform a more complex chain of different action movements different, accompanied by work, dancing, talking. Several years ago, when it was conceived, robot Nao enjoyed great success and increased global attractiveness.

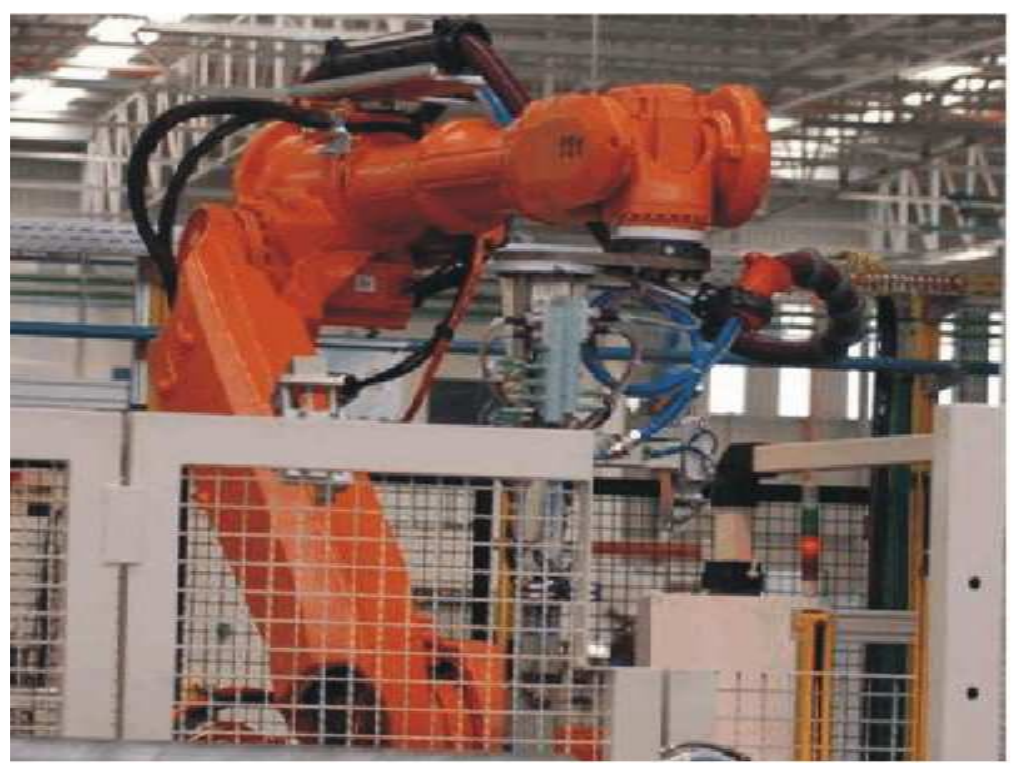

Fig. 6: An industrial robot

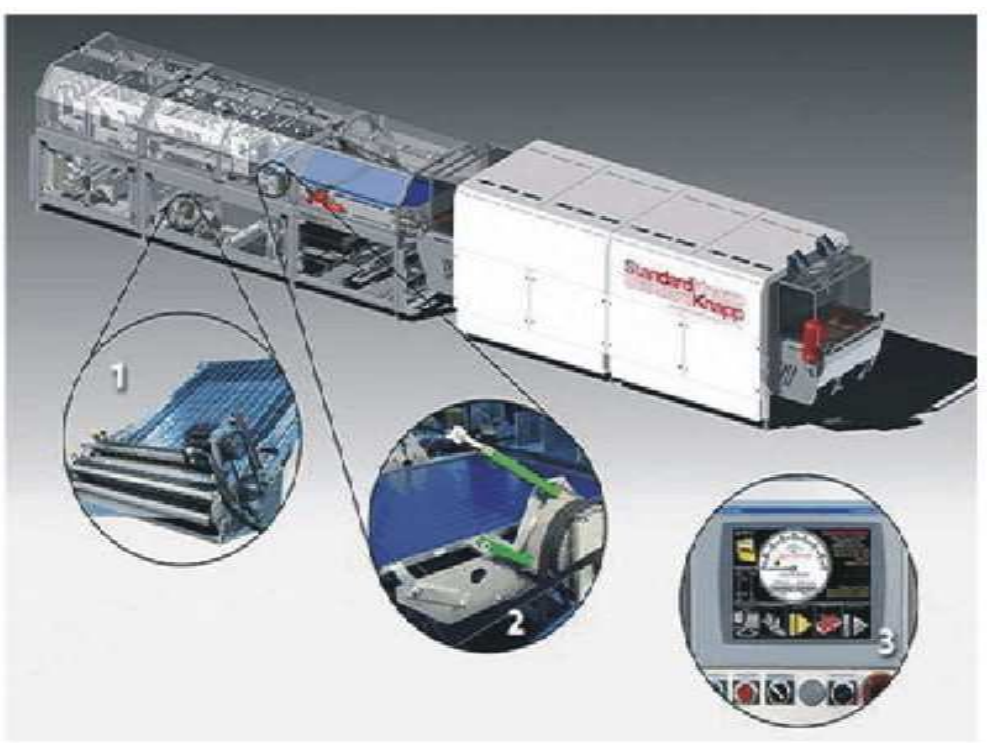

Fig. 7: A manufacturing cell 


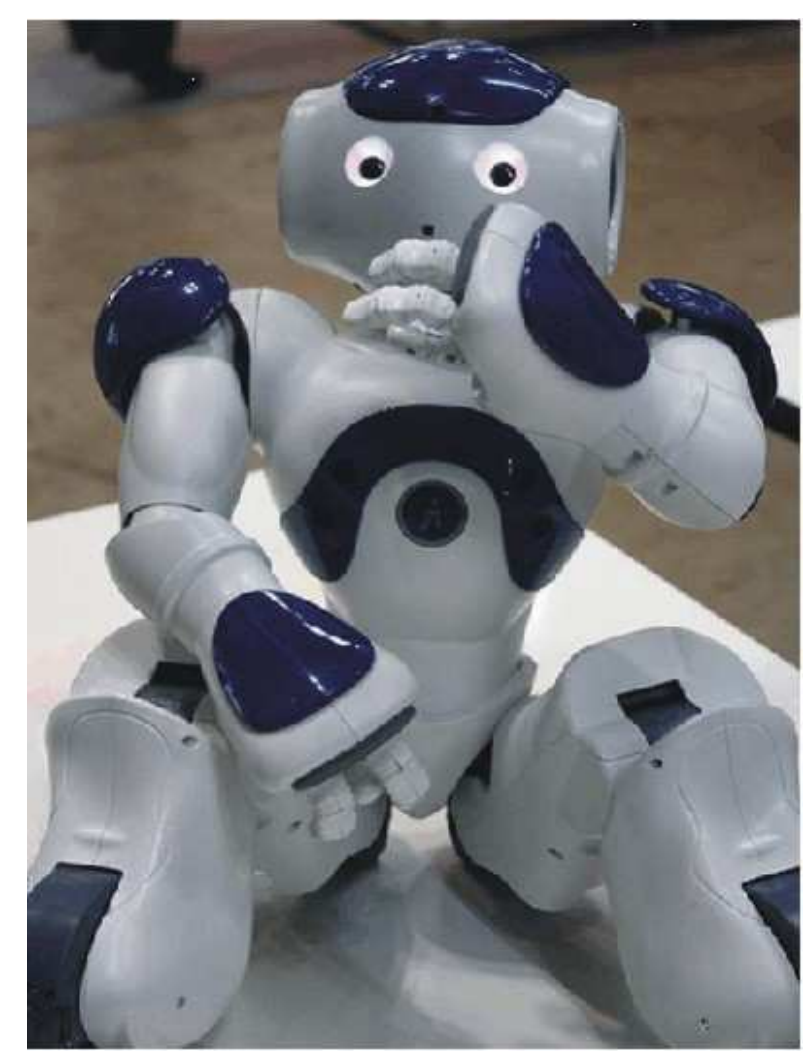

Fig. 8: The Nao robot

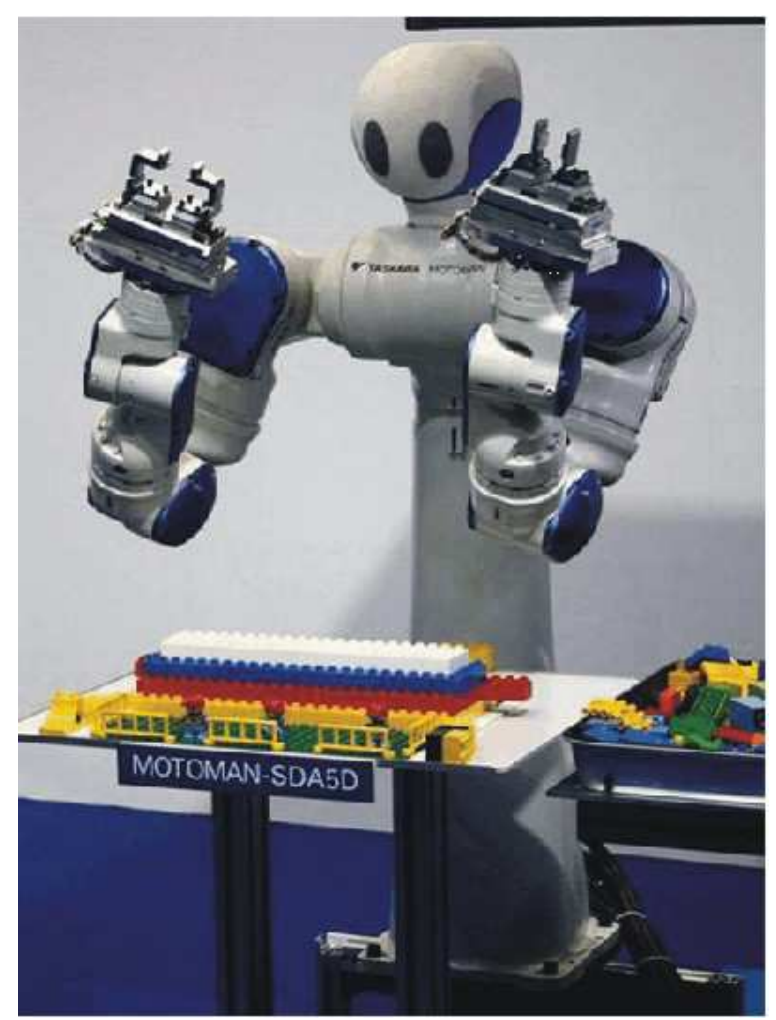

Fig. 9: The Motoman SDA5D

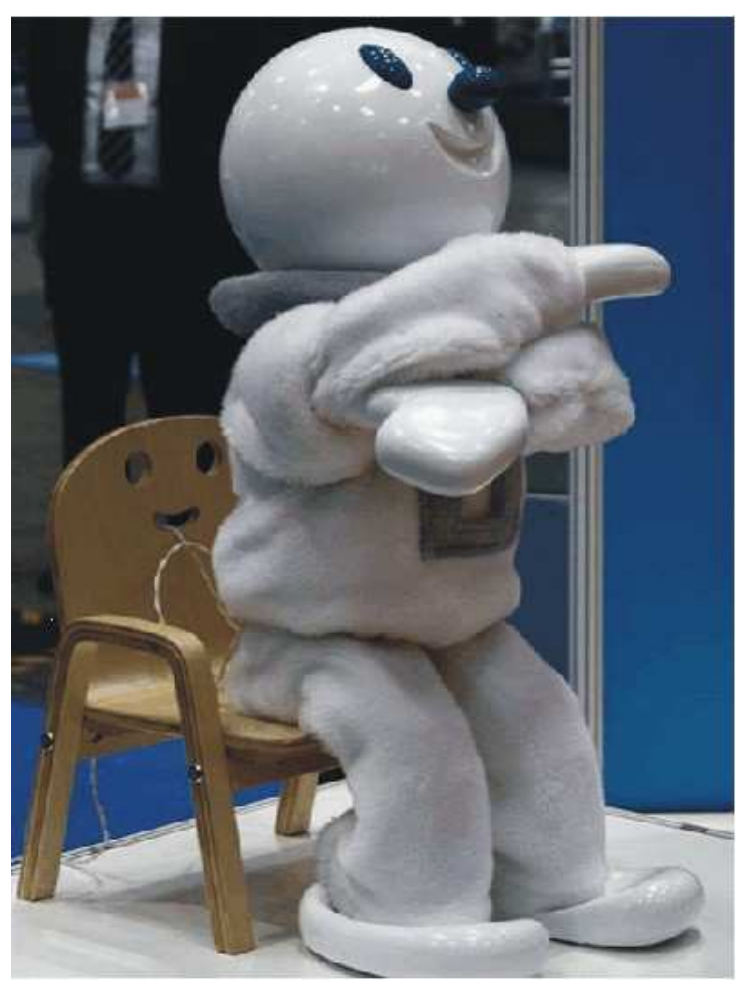

Fig. 10: A robot capable of playing with children and talking to them, socializing without scaring them

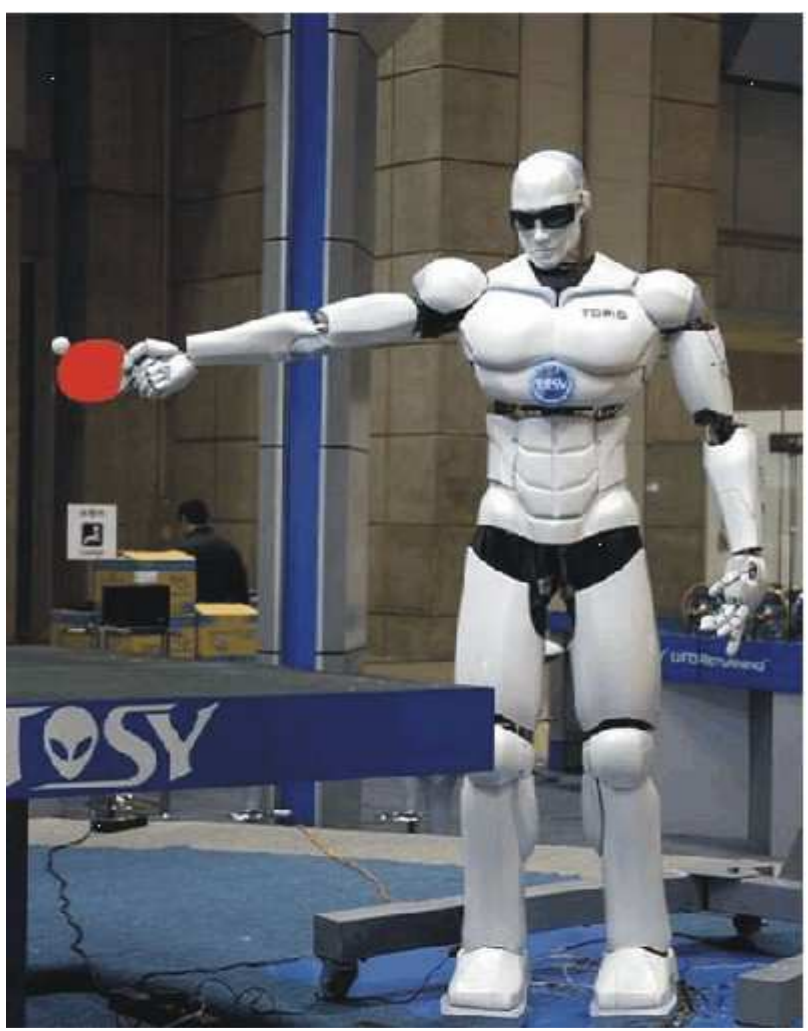

Fig. 11: A robot capable of play ping pong 
Motoman has introduced a robot capable of moving Lego pieces and even assembling them into a better building than a child (Fig. 9).

Figure 10 shows us a robot capable of playing with children and talking to them, socializing without scaring them.

Robots able to play ping pong are no longer a novelty, because they have been made in various constructive variants, having special capabilities in anticipating the position of the ball and in striking it correctly so that it will fall on the table as well (Fig. 11).

Honda's Asimo robot first learned to go and talk, socialize and then be useful by serving clients at a table (Fig. 12).
Honda's Asimo robot has grown up - with its latest upgrade giving it enhanced intelligence, added dexterity and the ability to run $5.6 \mathrm{mph}(9 \mathrm{~km} / \mathrm{h})$.

The first Asimo was created in 2000 and is seen as one of the leading attempts at creating a humanoid.

The latest version is able to change its actions depending on what happens around it - such as moving out of a person's way.

The $4 \mathrm{ft}(130 \mathrm{~cm})$-tall robot is also able to do complex sign language.

Asimo - which stands for Advanced Step in Innovative Mobility - is eventually intended to help people in various situations of need, such as the elderly, or those in disaster zones. It cannot yet be bought in shops.

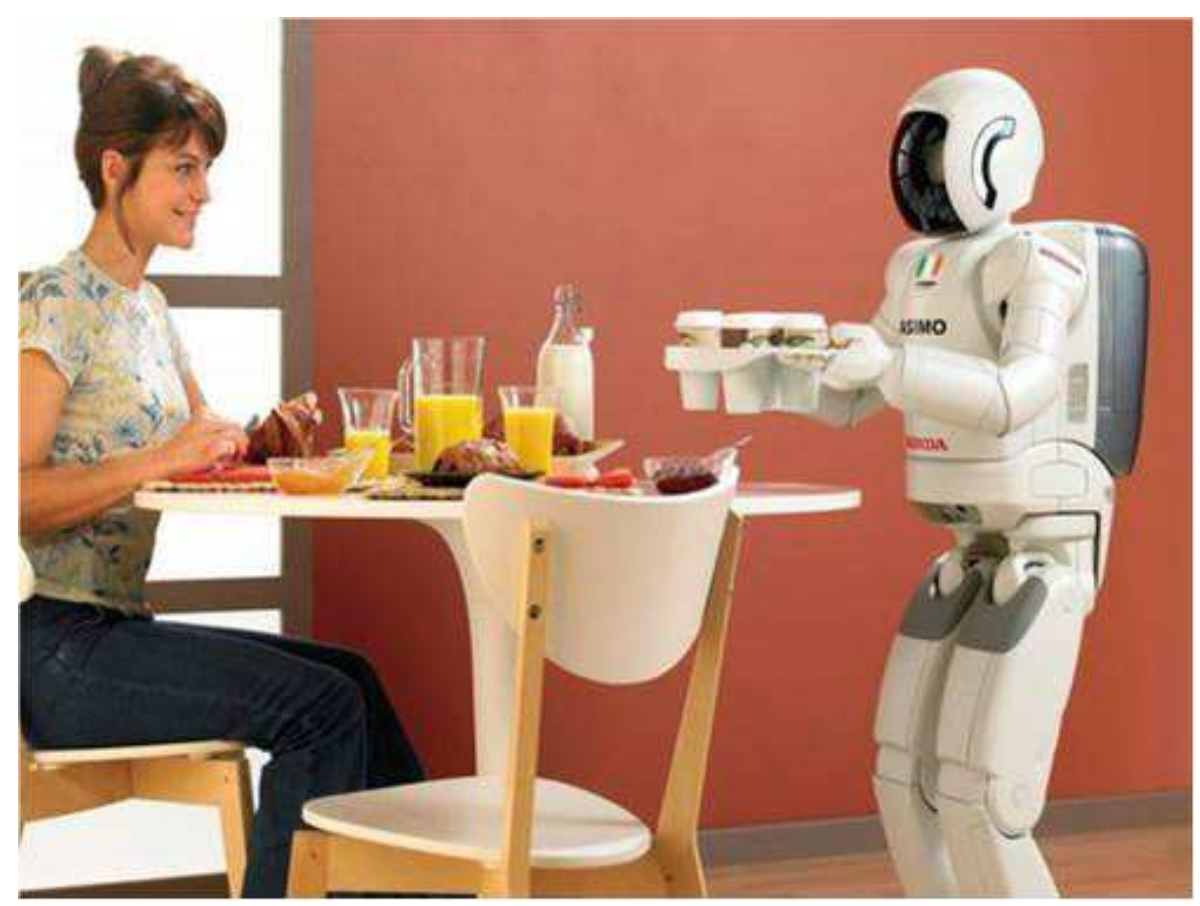

Fig. 12: A Honda's Asimo robot serving clients at a table

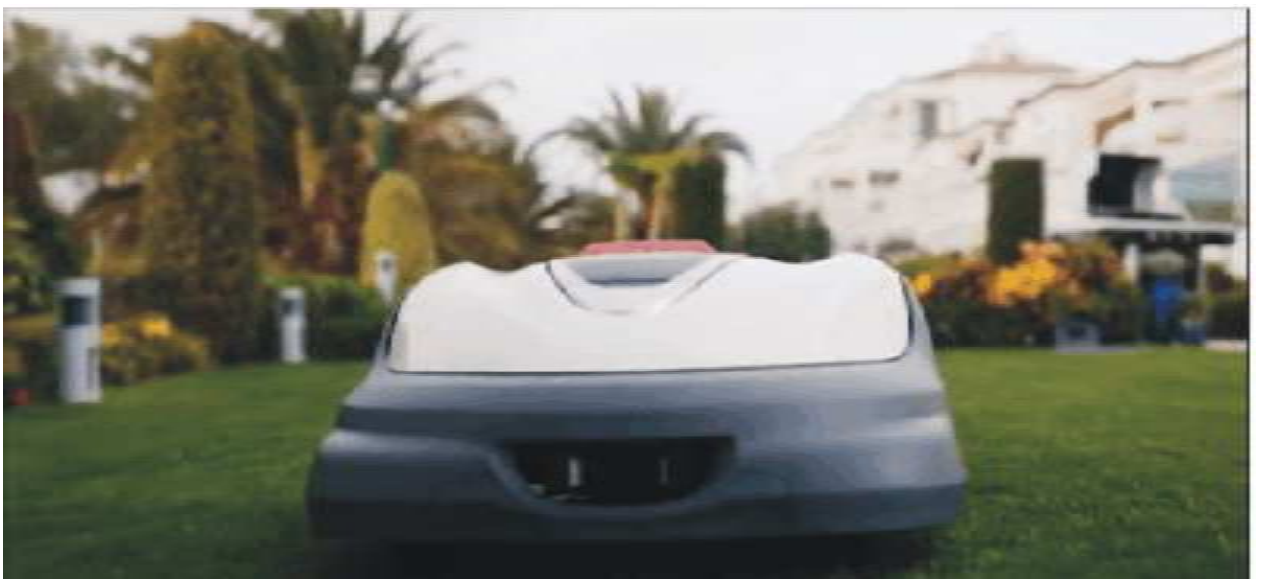

Fig. 13: Miimo is an autonomous robot produced by Honda that cuts grass in the yard or the lawn 
Parts of the technology developed by Honda for the Asimo project have been used to help clean-up efforts at the stricken Japanese nuclear plant Fukushima.

But in the humanoid robot, upgrades have focused on making Asimo better understand the world around itself.

Miimo is an autonomous robot produced by Honda that cuts grass in the yard or the lawn. The strongest model can cover an area of 4,000 square meters on a single battery charge (Fig. 13).

The robot can be set up via the dedicated Android, iOS-compliant app. Users can determine the time at which Miimo begins work, breaks, but also the height at which the vegetation cuts. The robot has a special dock that it goes alone to charge the battery after completing the tasks for which it was scheduled.

\section{Results}

Actroid is a type of android (humanoid robot) with strong visual human-likeness developed by Osaka University and manufactured by Kokoro Company Ltd. (the animatronics division of Sanrio).

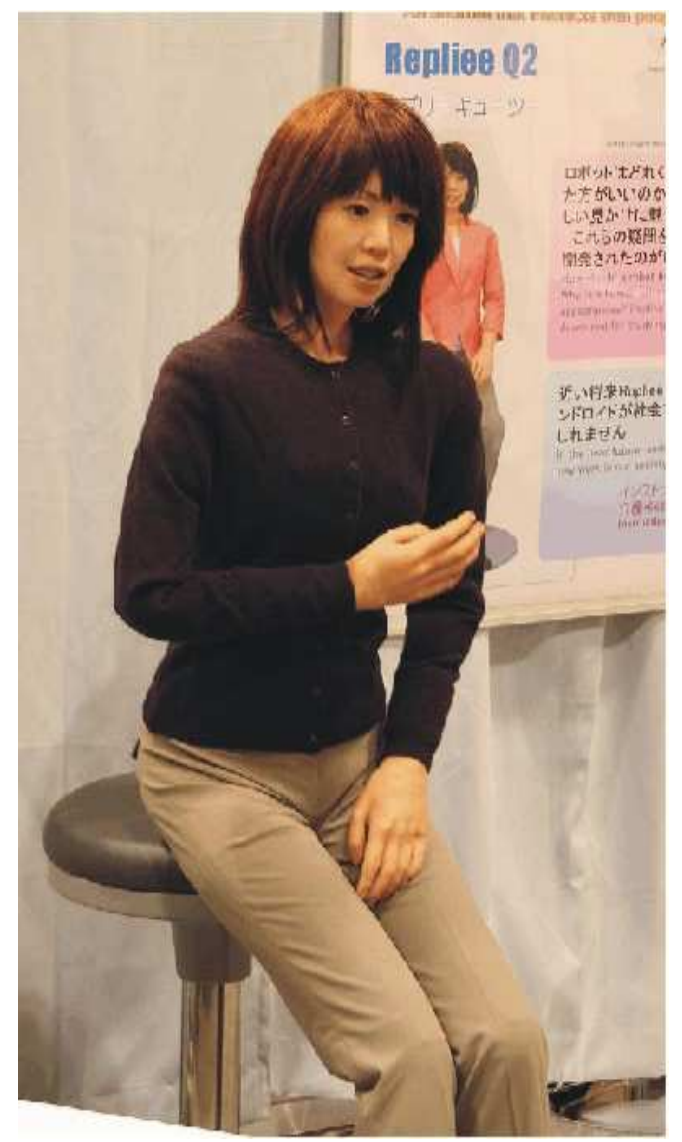

Fig. 14: Repliee Q2 can mimic such human functions as blinking, breathing and speaking, with the ability to recognize and process speech and touch and then respond in kind
It was first unveiled at the 2003 International Robot Exhibition in Tokyo, Japan. Several different versions of the product have been produced since then. In most cases, the robot's appearance has been modeled after an average young woman of Japanese descent.

The Actroid woman is a pioneering example of a real machine similar to imagined machines called by the science fiction terms android or gynoid, so far used only for fictional robots. It can mimic such lifelike functions as blinking, speaking and breathing. The "Repliee" models are interactive robots with the ability to recognize and process speech and respond in kind (Fig. 14 and 15).

The internal sensors allow Actroid models to react with a natural look by actuating body points. Early forms had 42 joints and the models later were 47 years old. Until now, the lower body movement is limited. Running the robot's sensational system in tandem with its air movements is fast enough to react or stop intrusive movements such as a slap or a beating. Artificial intelligence gives it the ability to react in a different way to milder touches, such as a bed on the arm.

The actress can also mimic human behavior similar to the luminous movements in the positions, head and eye movements and be breathing in the chest. In addition, the robot can be "taught" to mimic human movements by confronting a person who carries reflexive points in the body's key points. By tracking the points with his visual system and calculating the limbs and joints to fit what he sees, this movement can then be "learned" by the robot and repeated.

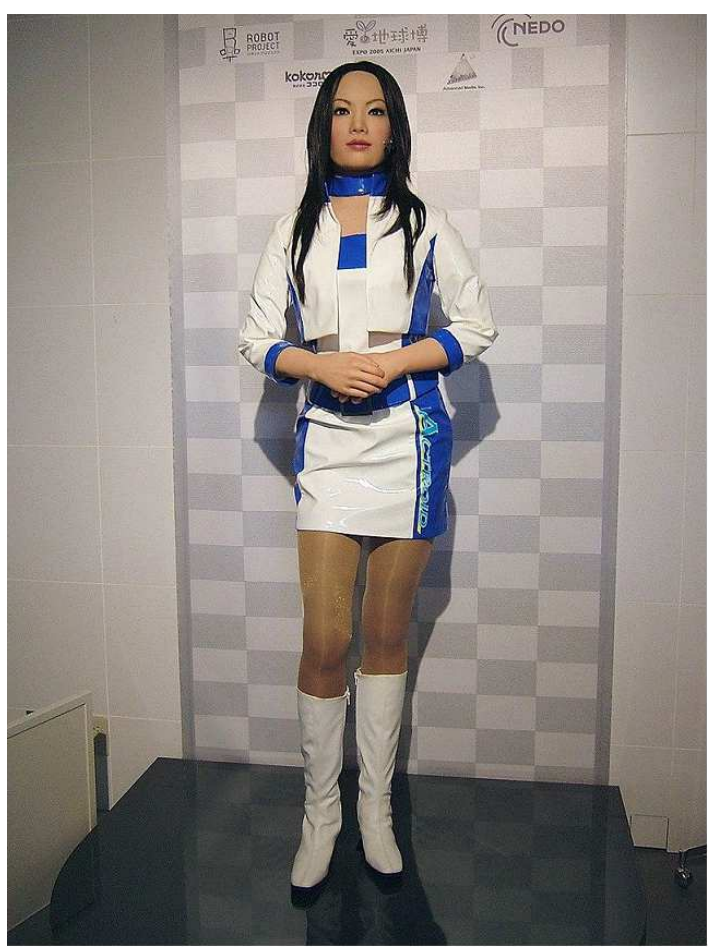

Fig. 15: Repliee Q1-expo, an actroid at Expo 2005 in Aichi 
The skin is silicone and looks extremely realistic. The compressed air acting on the engines of the robot engines and most of the hardware they operate is out of the machine. This is a contributing factor to the lack of robot locomotion. When displayed, the Actroid has always been seated or standing firmly supported.

Interactive actroid can also communicate rudimentarily with people, speaking. The microphones in these actroids record a man's speech and this sound is then filtered to eliminate background noise including the sounds of the robot's exploitation. Speech recognition technology is then used to convert the audio stream into words and sentences, which can then be processed by A.I. A verbal response is given by an external speaker to the unit.

Future interactivity is achieved through non-verbal methods. When approached, interactive actroids use a combination of "omnidirectional vision sensors and sensors" to maintain visual contact with the loudspeaker. In addition, robots can only respond to body language and tone of voice, changing their own facial expressions, position and vocal influence.

A humanoid robot is a body-shaped robot built to resemble the human body. The design may be for functional purposes, such as interaction with human instruments and media, for experimental purposes such as locomotor study or other purposes. Generally, humanoid robots have a trunk, a head, two arms and two legs, although some forms of humanoid robots can only form a part of the body, for example, from the waist up. Certain humanoid robots also have heads designed to reproduce the features of the human face, such as eyes and mouths. Androids are humanoid robots built to resemble aesthetically with humans.

An important requirement is that he can grasp both a heavy weight and an egg or bulb without breaking the latter. Touch tactile sensors play an extremely important role here (Fig. 16).

Arrays of tactels can be used to provide data on what has been touched. The Shadow Hand uses an array of 34 tactels arranged beneath its polyurethane skin on each fingertip. Tactile sensors also provide information about forces and torques transferred between the robot and other objects.

Vision refers to processing data from any modality which uses the electromagnetic spectrum to produce an image. In humanoid robots, it is used to recognize objects and determine their properties. Vision sensors work most similarly to the eyes of human beings. Most humanoid robots use CCD cameras as vision sensors.

Sound sensors allow humanoid robots to hear speech and environmental sounds and perform as the ears of the human being. Microphones are usually used for this task.

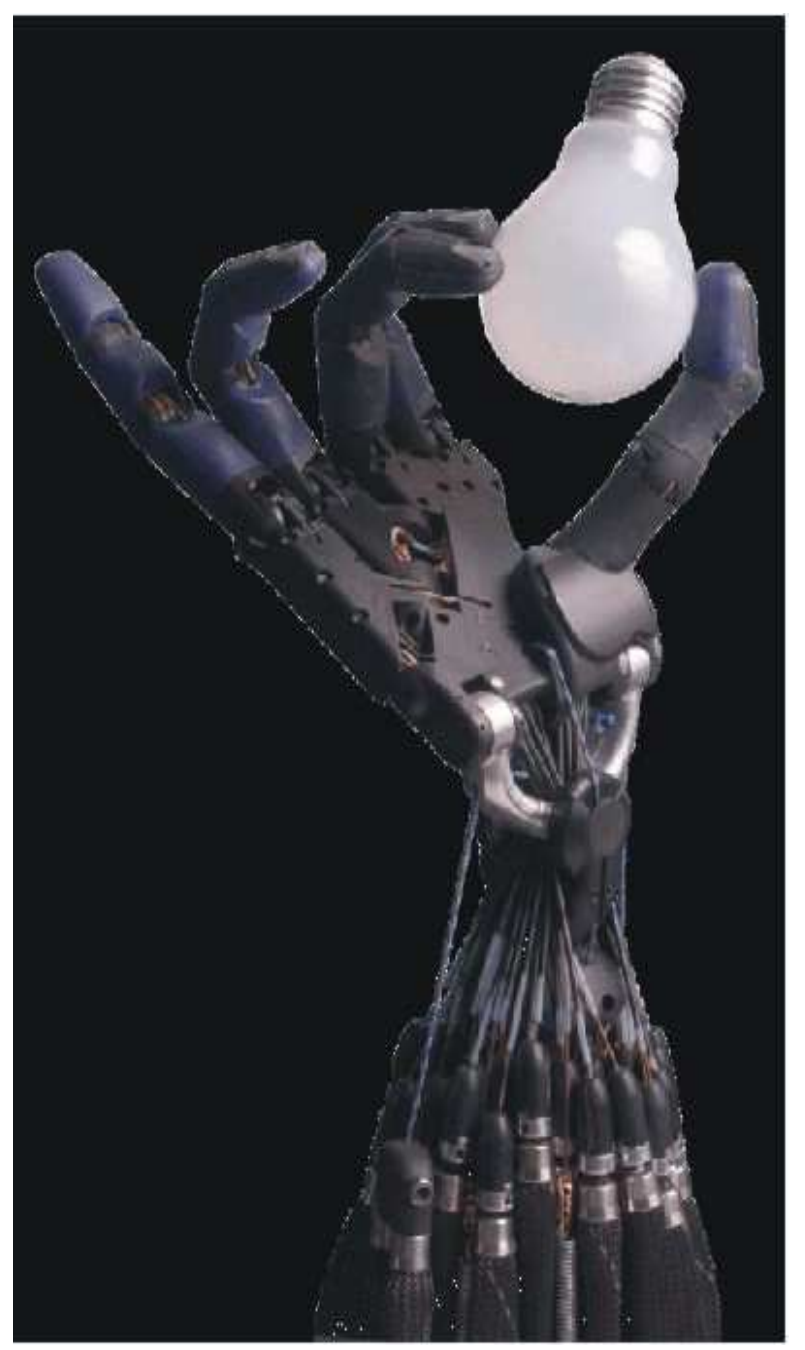

Fig. 16: An artificial hand holding a lightbulb

In planning and control, the essential difference between humanoids and other types of robots (such as industrial ones) is that robot movement should be similar to human movement, using foot movement, especially walking. Ideal planning for humanoid movements during normal exercise should result in minimal energy consumption, as is the case with the human body. For this reason, studies on the dynamics and control of these types of structures have become increasingly important.

The problem of stabilizing robots on walking streets is very important. Keeping the robot's center of gravity above the center of the support area to ensure a stable position can be chosen as a control lens.

To maintain dynamic balance while driving, a robot needs information about the contact force and the current and desired movement. The solution to this problem is based on a major concept, Zero Moment Point (ZMP). 
Another feature of humanoid robots is that they move, gather information (using sensors) on the "real world" and interact with them. They do not remain as factory manipulators and other robots working in highly structured environments. To enable humanoids to move into complex environments, planning and control should focus on detecting auto collides, planning the route and avoiding obstacles.

Certain humanoid robots do not yet have the features of the human body. These include structures with the variable flexibility that provide security (robot and people) and redundancy, i.e. multiple degrees of freedom and hence the high availability of tasks. Although these characteristics are desirable for humanoid robots, they will bring more complexity and new planning and control issues. The scope of the body control deals with these issues and addresses the appropriate coordination of multiple degrees of freedom, simultaneously performing multiple control tasks, following a certain order of priority.

\section{Discussion}

It started from the robots needed in the machine building industry (Fig. 17) and now any type of robot is manufactured, with various purposes and uses, so we can say that it was robots on our planet has already started successfully.

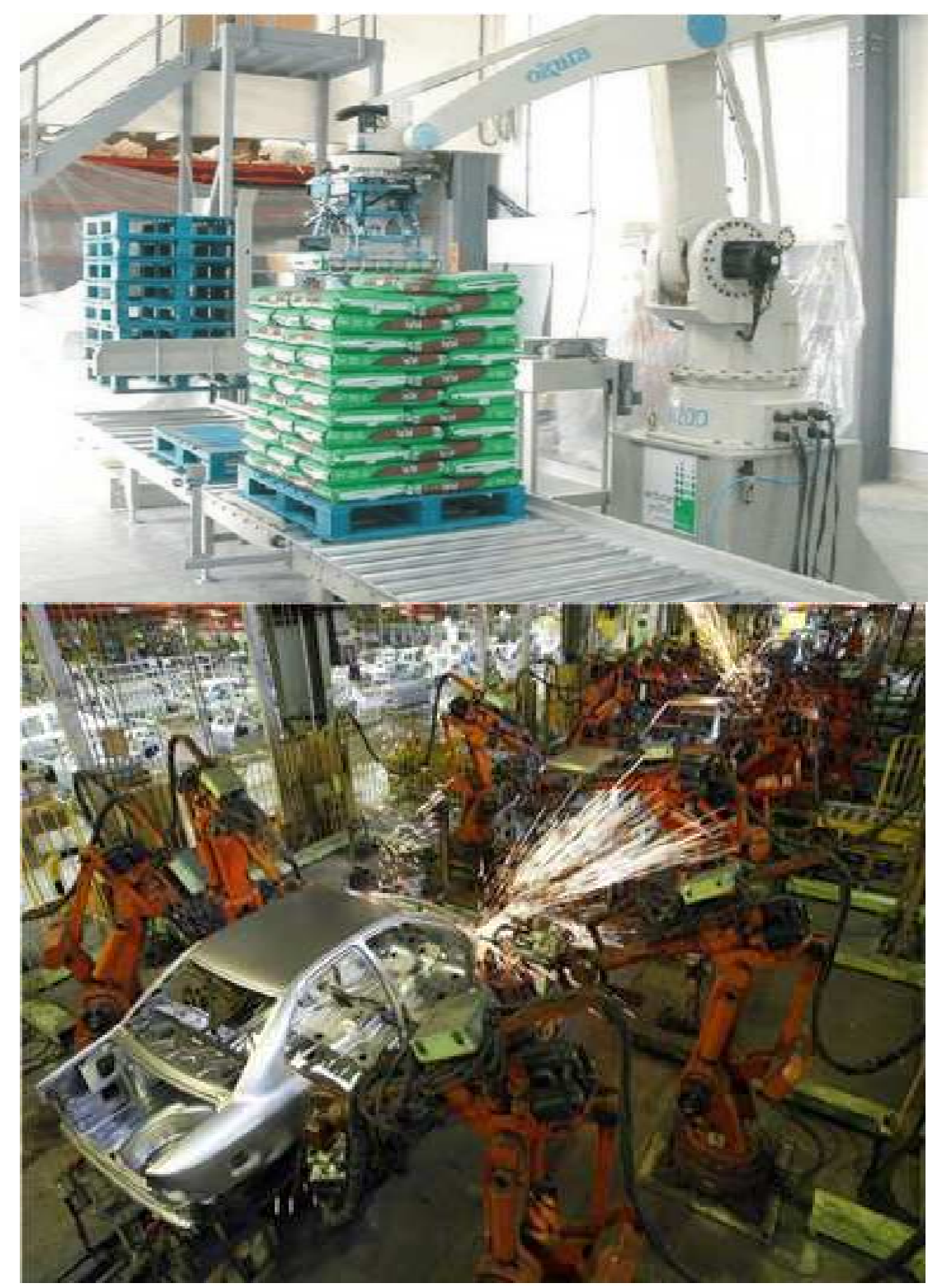

Fig. 17: Some robots needed in the machine building industry 


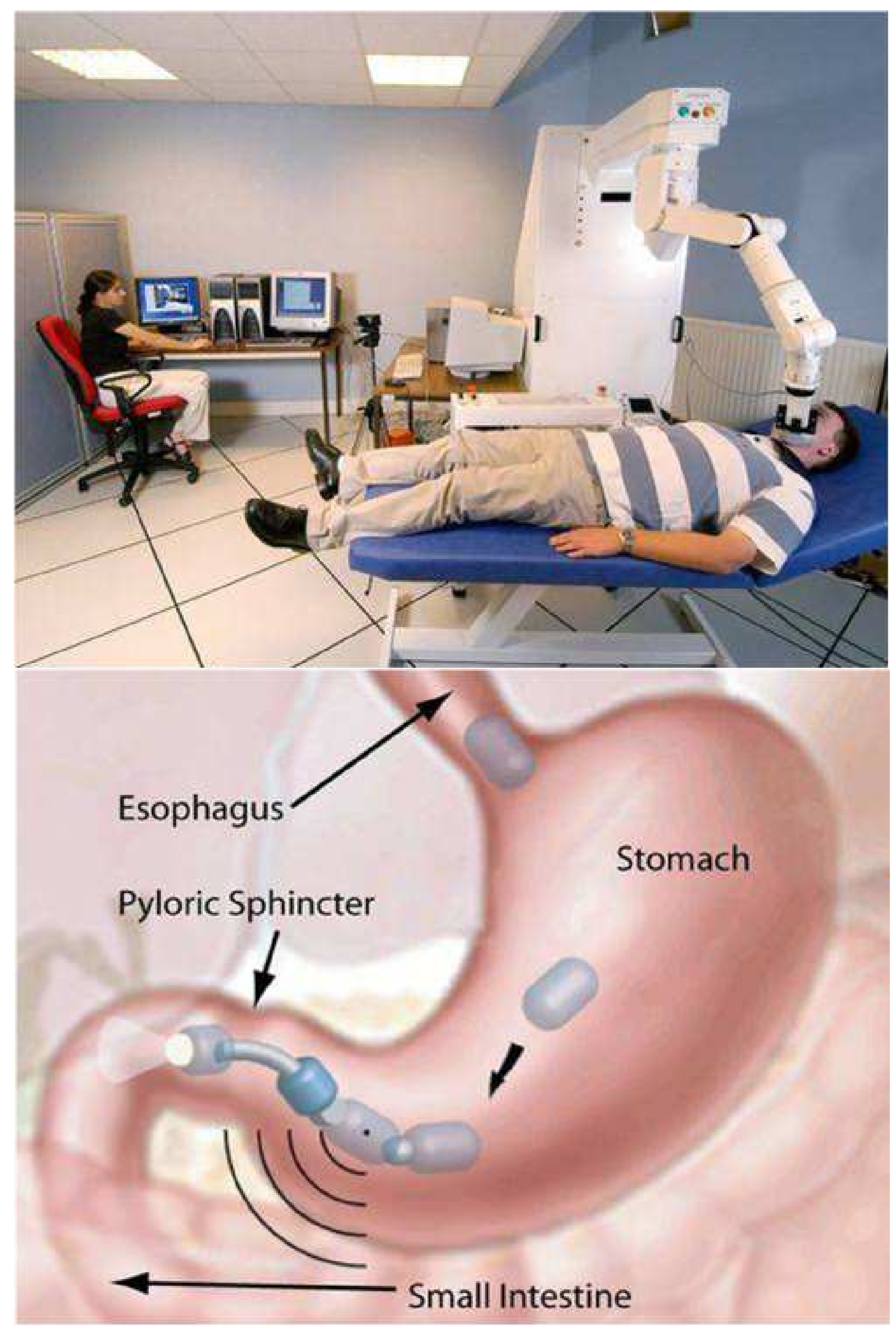

Fig. 18: Robots to help us in various difficult applications to the human, the surgeon in the operating blocks 


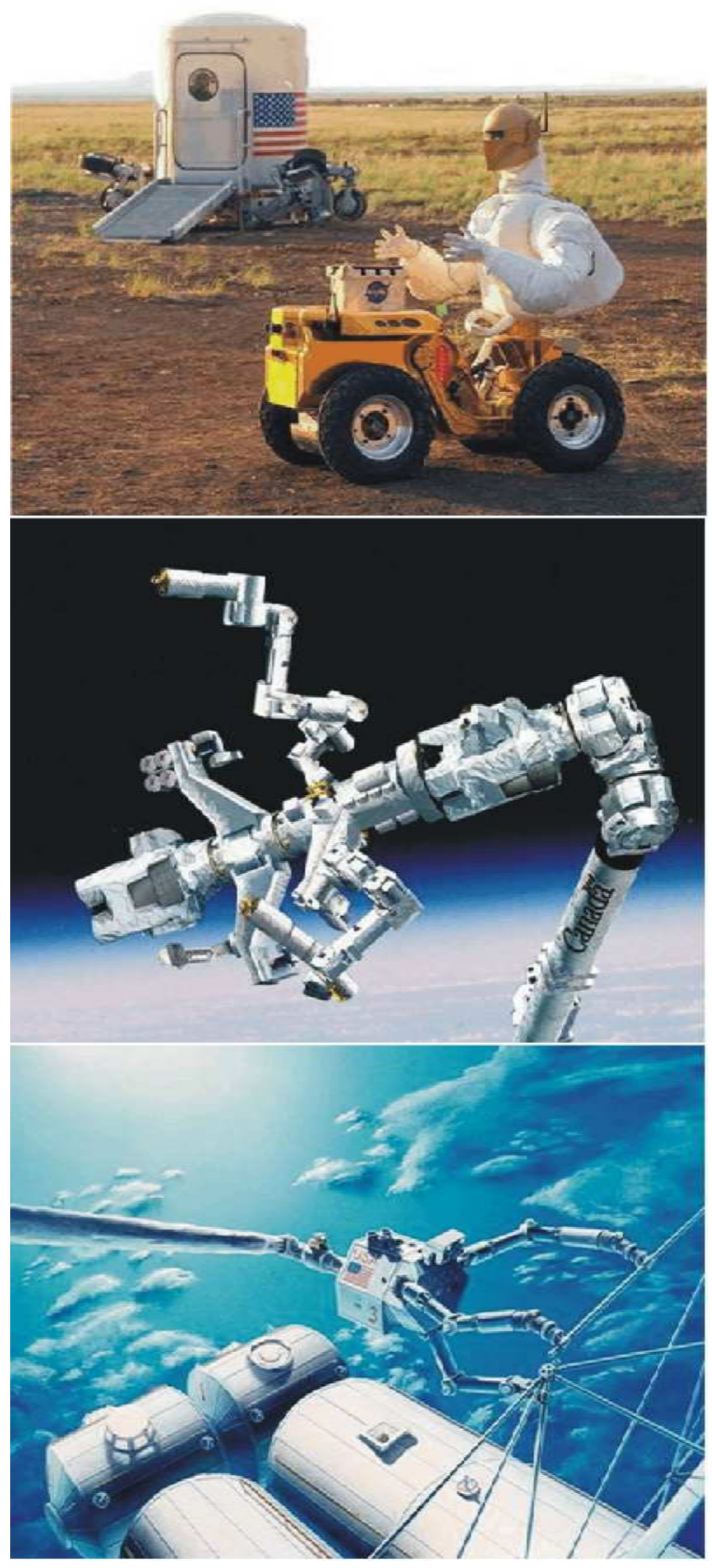

Fig. 19: Robots will help us colonize the cosmic space 

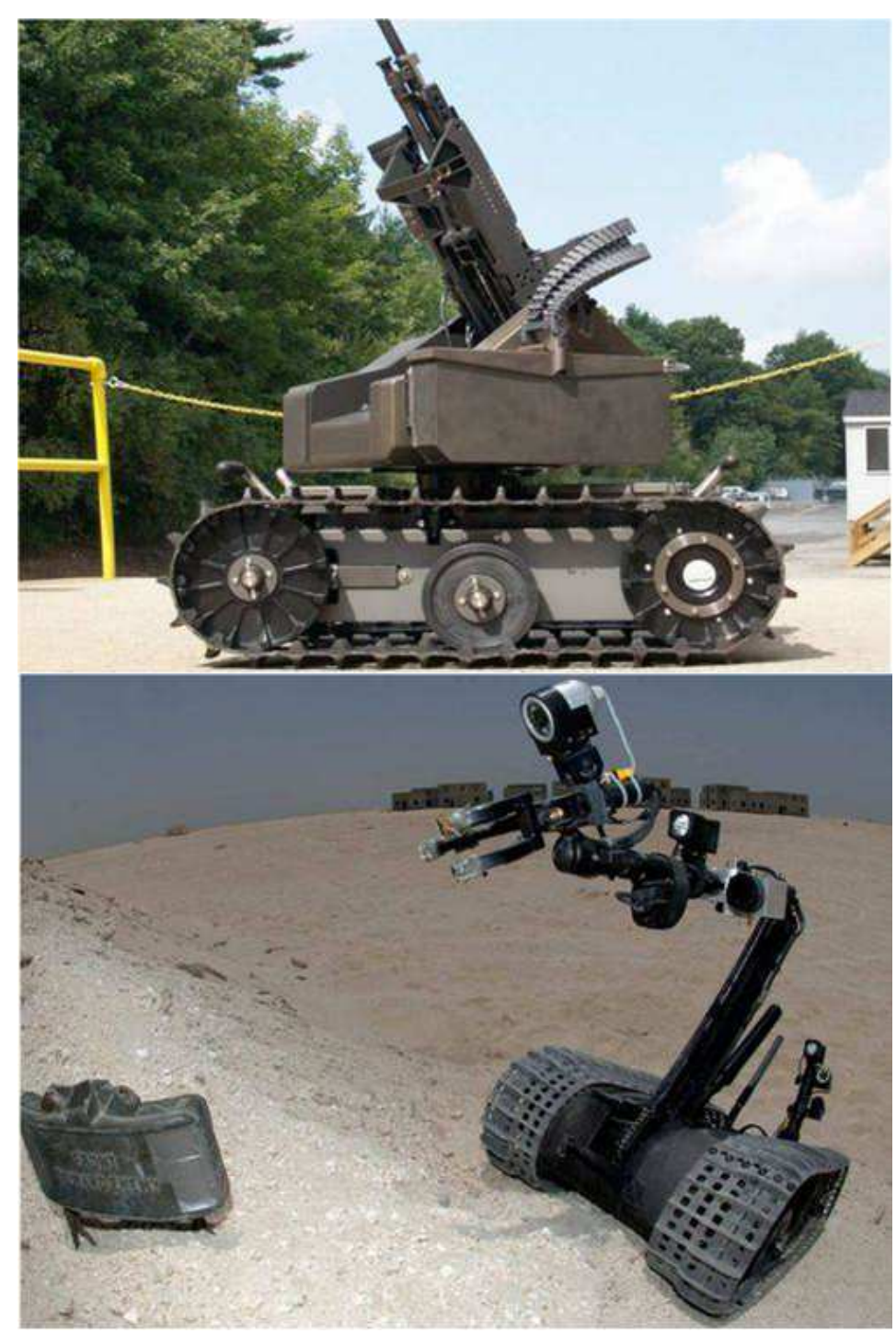

Fig. 20: Many robots will develop to have great combat capabilities

They have succeeded in making our lives easier, more comfortable, more enjoyable and have taken up heavy labors, being treated at the beginning as slaves long released, but even without their acceptance, on the basis that they are only useful cars man, for the time being.

It is very important that we slowly but surely determine the robots to help us in various difficult applications to the human, the surgeon in the operating blocks (Fig. 18), then to the fine positioning of the observation satellites, the powerful telescopes that help us find new living planets and soon the robots will be a means of helping man to conquer the cosmic space.

They will be conducting spacecraft, they already do it in our solar system but some of them have gone beyond it, they will explore the Martian soil or other planets and satellites, will help us colonize the cosmic space (Fig. 19) and will be able to defend us from the possible enemies that might occur, which is why many robots will develop to have great combat capabilities (Fig. 20).

\section{Conclusion}

It is very important that we slowly but surely determine the robots to help us in various difficult applications to the human, the surgeon in the operating blocks, then to the fine positioning of the observation satellites, the powerful telescopes that help us find new living planets and soon the robots will be a means of helping man to conquer the cosmic space.

They will be conducting spacecraft, they already do it in our solar system but some of them have gone beyond it, they will explore the Martian soil or other planets and satellites, will help us colonize the cosmic space and will be able to defend us from the possible enemies that 
might occur, which is why many robots will develop to have great combat capabilities.

\section{Acknowledgement}

This text was acknowledged and appreciated by Dr. Veturia CHIROIU Honorific member of Technical Sciences Academy of Romania (ASTR) PhD supervisor in Mechanical Engineering.

\section{Funding Information}

Research contract: 1-Research contract: Contract number 36-5-4D/1986 from 24IV1985, beneficiary CNST RO (Romanian National Center for Science and Technology) Improving dynamic mechanisms.

2-Contract research integration. 19-91-3 from 29.03.1991; Beneficiary: MIS; TOPIC: Research on designing mechanisms with bars, cams and gears, with application in industrial robots.

3-Contract research. GR 69/10.05.2007: NURC in 2762; theme 8: Dynamic analysis of mechanisms and manipulators with bars and gears.

4-Labor contract, no. 35/22.01.2013, the UPB, "Stand for reading performance parameters of kinematics and dynamic mechanisms, using inductive and incremental encoders, to a Mitsubishi Mechatronic System" "PN-IIIN-CI-2012-1-0389".

All these matters are copyrighted! Copyrights: 394qodGnhhtej, from 17-02-2010 13:42:18; 463vpstuCGsiy, from 20-03-2010 12:45:30; 631sqfsgquutm, from 24-05-2010 16:15:22; 933CrDztEfqow, from 07-01-2011 13:37:52.

\section{Author's Contributions}

This section should state the contributions made by each author in the preparation, development and publication of this manuscript.

\section{Ethics}

Authors should address any ethical issues that may arise after the publication of this manuscript.

\section{References}

Antonescu, P. and F. Petrescu, 1985. An analytical method of synthesis of cam mechanism and flat stick. Proceedings of the 4th International Symposium on Theory and Practice of Mechanisms, (TPM' 89), Bucharest.

Antonescu, P. and F. Petrescu, 1989. Contributions to kinetoplast dynamic analysis of distribution mechanisms. Bucharest.
Antonescu, P., M. Oprean and F. Petrescu, 1985a. Contributions to the synthesis of oscillating cam mechanism and oscillating flat stick. Proceedings of the 4th International Symposium on Theory and Practice of Mechanisms, (TPM' 85), Bucharest.

Antonescu, P., M. Oprean and F. Petrescu, 1985b. At the projection of the oscillate cams, there are mechanisms and distribution variables. Proceedings of the 5th Conference of Engines, Automobiles, Tractors and Agricultural Machines, (TAM' 58), IMotors and Cars, Brasov.

Antonescu, P., M. Oprean and F. Petrescu, 1986. Projection of the profile of the rotating camshaft acting on the oscillating plate with disengagement. Proceedings of the 3rd National Computer-aided Design Symposium in the field of Mechanisms and Machine Parts, (MMP' 86), Brasov.

Antonescu, P., M. Oprean and F. Petrescu, 1987. Dynamic analysis of the cam distribution mechanisms. Proceedings of the 7th National Symposium on Industrial Robots and Space Mechanisms, (RSM' 87), Bucharest.

Antonescu, P., M. Oprean and F. Petrescu, 1988. Analytical synthesis of Kurz profile, rotating the flat cam. Mach, Build. Rev.

Antonescu, P., F. Petrescu and O. Antonescu, 1994. Contributions to the synthesis of the rotating cam mechanism and the tip of the balancing tip. Brasov.

Antonescu, P., F. Petrescu and D. Antonescu, 1997. Geometrical synthesis of the rotary cam and balance tappet mechanism. Bucharest, 3: 23-23.

Antonescu, P., F. Petrescu and O. Antonescu, 2000a. Contributions to the synthesis of the rotary disc-cam profile. Proceedings of the 8th International Conference on the Theory of Machines and Mechanisms, (TMM' 00), Liberec, Czech Republic, pp: 51-56.

Antonescu, P., F. Petrescu and O. Antonescu, 2000b. Synthesis of the rotary cam profile with balance follower. Proceedings of the 8th Symposium on Mechanisms and Mechanical Transmissions, (MMT'00), Timişoara, pp: 39-44.

Antonescu, P., F. Petrescu and O. Antonescu, 2001. Contributions to the synthesis of mechanisms with rotary disc-cam. Proceedings of the 8th IFToMM International Symposium on Theory of Machines and Mechanisms, (TMM' 01), Bucharest, ROMANIA, pp: 31-36.

Aversa, R., R.V.V. Petrescu, A. Apicella and F.I.T. Petrescu, 2017a. Nano-diamond hybrid materials for structural biomedical application. Am. J. Biochem. Biotechnol., 13: 34-41.

DOI: $10.3844 /$ ajbbsp.2017.34.41 
Aversa, R., R.V. Petrescu, B. Akash, R.B. Bucinell and J.M. Corchado et al., 2017b. Kinematics and forces to a new model forging manipulator. Am. J. Applied Sci., 14: 60-80. DOI: 10.3844/ajassp.2017.60.80

Aversa, R., R.V. Petrescu, A. Apicella, F.I.T. Petrescu and J.K. Calautit et al., 2017c. Something about the V engines design. Am. J. Applied Sci., 14: 34-52. DOI: 10.3844/ajassp.2017.34.52

Aversa, R., D. Parcesepe, R.V.V. Petrescu, F. Berto and G. Chen et al., 2017d. Process ability of bulk metallic glasses. Am. J. Applied Sci., 14: 294-301. DOI: 10.3844/ajassp.2017.294.301

Aversa, R., R.V.V. Petrescu, B. Akash, R.B. Bucinell and J.M. Corchado et al., 2017e. Something about the balancing of thermal motors. Am. J. Eng. Applied Sci., 10: 200.217. DOI: 10.3844 /ajeassp.2017.200.217

Aversa, R., F.I.T. Petrescu, R.V. Petrescu and A. Apicella, 2016a. Biomimetic FEA bone modeling for customized hybrid biological prostheses development. Am. J. Applied Sci., 13: 1060-1067. DOI: 10.3844/ajassp.2016.1060.1067

Aversa, R., D. Parcesepe, R.V. Petrescu, G. Chen and F.I.T. Petrescu et al., 2016b. Glassy amorphous metal injection molded induced morphological defects. Am. J. Applied Sci., 13: 1476-1482.

DOI: 10.3844/ajassp.2016.1476.1482

Aversa, R., R.V. Petrescu, F.I.T. Petrescu and A. Apicella, 2016c. Smart-factory: Optimization and process control of composite centrifuged pipes. Am. J. Applied Sci., 13: 1330-1341.

DOI: 10.3844/ajassp.2016.1330.1341

Aversa, R., F. Tamburrino, R.V. Petrescu, F.I.T. Petrescu and M. Artur et al., 2016d. Biomechanically inspired shape memory effect machines driven by muscle like acting NiTi alloys. Am. J. Applied Sci., 13: 1264-1271. DOI: 10.3844/ajassp.2016.1264.1271

Aversa, R., E.M. Buzea, R.V. Petrescu, A. Apicella and M. Neacsa et al., 2016e. Present a mechatronic system having able to determine the concentration of carotenoids. Am. J. Eng. Applied Sci., 9: 1106-1111. DOI: 10.3844/ajeassp.2016.1106.1111

Aversa, R., R.V. Petrescu, R. Sorrentino, F.I.T. Petrescu and A. Apicella, 2016f. Hybrid ceramo-polymeric nanocomposite for biomimetic scaffolds design and preparation. Am. J. Eng. Applied Sci., 9: 1096-1105. DOI: 10.3844/ajeassp.2016.1096.1105

Aversa, R., V. Perrotta, R.V. Petrescu, C. Misiano and F.I.T. Petrescu et al., 2016g. From structural colors to super-hydrophobicity and achromatic transparent protective coatings: Ion plating plasma assisted $\mathrm{TiO}_{2}$ and $\mathrm{SiO}_{2}$ nano-film deposition. Am. J. Eng. Applied Sci., 9: 1037-1045.

DOI: $10.3844 /$ ajeassp.2016.1037.1045
Aversa, R., R.V. Petrescu, F.I.T. Petrescu and A. Apicella, 2016h. Biomimetic and evolutionary design driven innovation in sustainable products development. Am. J. Eng. Applied Sci., 9: 1027-1036. DOI: 10.3844/ajeassp.2016.1027.1036

Aversa, R., R.V. Petrescu, A. Apicella and F.I.T. Petrescu, 2016i. Mitochondria are naturally micro robots - a review. Am. J. Eng. Applied Sci., 9: 991-1002.

DOI: 10.3844/ajeassp.2016.991.1002

Aversa, R., R.V. Petrescu, A. Apicella and F.I.T. Petrescu, 2016j. We are addicted to vitamins $\mathrm{C}$ and E-A review. Am. J. Eng. Applied Sci., 9: 1003-1018. DOI: 10.3844/ajeassp.2016.1003.1018

Aversa, R., R.V. Petrescu, A. Apicella and F.I.T. Petrescu, 2016k. Physiologic human fluids and swelling behavior of hydrophilic biocompatible hybrid ceramo-polymeric materials. Am. J. Eng. Applied Sci., 9: 962-972.

DOI: 10.3844 /ajeassp.2016.962.972

Aversa, R., R.V. Petrescu, A. Apicella and F.I.T. Petrescu, 20161. One can slow down the aging through antioxidants. Am. J. Eng. Applied Sci., 9: 1112-1126. DOI: 10.3844/ajeassp.2016.1112.1126

Aversa, R., R.V. Petrescu, A. Apicella and F.I.T. Petrescu, 2016m. About homeopathy or «Similia Similibus Curentur 》. Am. J. Eng. Applied Sci., 9: 1164-1172. DOI: 10.3844/ajeassp.2016.1164.1172

Aversa, R., R.V. Petrescu, A. Apicella and F.I.T. Petrescu, 2016n. The basic elements of life's. Am. J. Eng. Applied Sci., 9: 1189-1197. DOI: 10.3844/ajeassp.2016.1189.1197

Aversa, R., F.I.T. Petrescu, R.V. Petrescu and A. Apicella, 2016o. Flexible stem trabecular prostheses. Am. J. Eng. Applied Sci., 9: 1213-1221. DOI: 10.3844/ajeassp.2016.1213.1221

Berto, F., R.V.V. Petrescu and F.I.T. Petrescu, 2016a. A review of recent results on $3 \mathrm{D}$ effects. Am. J. Eng. Applied Sci., 9: 1247-1260.

DOI: 10.3844/ajeassp.2016.1247.1260

Berto, F., R.V.V. Petrescu and F.I.T. Petrescu, 2016 b. Three-dimensional in bonded joints: A short review. Am. J. Eng. Applied Sci., 9: 1261-1268. DOI: 10.3844 /ajeassp.2016.1261.1268

Berto, F., A. Gagani, R.V.V. Petrescu and F.I.T. Petrescu, 2016c. Key-hole notches in isostatic graphite: A review of some recent data. Am. J. Eng. Applied Sci., 9: 1292-1300. DOI: 10.3844/ajeassp.2016.1292.1300

Berto, F., A. Gagani, R. Aversa, R.V.V. Petrescu and A. Apicella et al., 2016d. Multiaxial fatigue strength to notched specimens made of 40CrMoV13.9. Am. J. Eng. Applied Sci., 9: 1269-1291. DOI: 10.3844/ajeassp.2016.1269.1291 
Cao, W., H. Ding, Z. Bin and C. Ziming, 2013. New structural representation and digital-analysis platform for symmetrical parallel mechanisms. Int. J. Adv. Robotic Sys. DOI: 10.5772/56380

Comanescu, A., 2010. Bazele Modelarii Mecanismelor. 1st Edn., E. Politeh, Press, București, pp: 274.

Dong, H., N. Giakoumidis, N. Figueroa and N. Mavridis, 2013. Approaching behaviour monitor and vibration indication in developing a General Moving Object Alarm System (GMOAS). Int. J. Adv. Robotic Sys. DOI: $10.5772 / 56586$

Franklin, D.J., 1930. Ingenious Mechanisms for Designers and Inventors. 1st Edn., Industrial Press Publisher.

He, B., Z. Wang, Q. Li, H. Xie and R. Shen, 2013. An analytic method for the kinematics and dynamics of a multiple-backbone continuum robot. IJARS. DOI: $10.5772 / 54051$

Lee, B.J., 2013. Geometrical derivation of differential kinematics to calibrate model parameters of flexible manipulator. Int. J. Adv. Robotic Sys. DOI: $10.5772 / 55592$

Lin, W., B. Li, X. Yang and D. Zhang, 2013. Modelling and control of inverse dynamics for a 5-DOF parallel kinematic polishing machine. Int. J. Adv. Robotic Sys. DOI: 10.5772/54966

Liu, H., W. Zhou, X. Lai and S. Zhu, 2013. An efficient inverse kinematic algorithm for a PUMA560structured robot manipulator. IJARS. DOI: $10.5772 / 56403$

Mirsayar, M.M., V.A. Joneidi, R.V.V. Petrescu, F.I.T. Petrescu and F. Berto, 2017. Extended MTSN criterion for fracture analysis of soda lime glass. Eng. Fracture Mechan., 178: 50-59.

DOI: 10.1016/j.engfracmech.2017.04.018

Padula, F. and V. Perdereau, 2013. An on-line path planner for industrial manipulators. Int. J. Adv. Robotic Sys. DOI: 10.5772/55063

Perumaal, S. and N. Jawahar, 2013. Automated trajectory planner of industrial robot for pick-andplace task. IJARS. DOI: 10.5772/53940

Petrescu, F. and R. Petrescu, 1995a. Contributions to optimization of the polynomial motion laws of the stick from the internal combustion engine distribution mechanism. Bucharest, 1: 249-256.

Petrescu, F. and R. Petrescu, 1995b. Contributions to the synthesis of internal combustion engine distribution mechanisms. Bucharest, 1: 257-264.

Petrescu, F. and R. Petrescu, 1997a. Dynamics of cam mechanisms (exemplified on the classic distribution mechanism). Bucharest, 3: 353-358.

Petrescu, F. and R. Petrescu, 1997b. Contributions to the synthesis of the distribution mechanisms of internal combustion engines with a Cartesian coordinate method. Bucharest, 3: 359-364.
Petrescu, F. and R. Petrescu, 1997c. Contributions to maximizing polynomial laws for the active stroke of the distribution mechanism from internal combustion engines. Bucharest, 3: 365-370.

Petrescu, F. and R. Petrescu, 2000a. Synthesis of distribution mechanisms by the rectangular (Cartesian) coordinate method. Proceedings of the 8th National Conference on International Participation, (CIP' 00), Craiova, Romania, pp: 297-302.

Petrescu, F. and R. Petrescu, 2000b. The design (synthesis) of cams using the polar coordinate method (triangle method). Proceedings of the 8th National Conference on International Participation, (CIP' 00), Craiova, Romania, pp: 291-296.

Petrescu, F. and R. Petrescu, 2002a. Motion laws for cams. Proceedings of the International Computer Assisted Design, National Symposium with Participation, (SNP' 02), Braşov, pp: 321-326.

Petrescu, F. and R. Petrescu, 2002b. Camshaft dynamics elements. Proceedings of the International Computer Assisted Design, National Participation Symposium, (SNP' 02), Braşov, pp: 327-332.

Petrescu, F. and R. Petrescu, 2003. Some elements regarding the improvement of the engine design. Proceedings of the National Symposium, Descriptive Geometry, Technical Graphics and Design, (GTD' 03), Braşov, pp: 353-358.

Petrescu, F. and R. Petrescu, 2005a. The cam design for a better efficiency. Proceedings of the International Conference on Engineering Graphics and Design, (EGD’05), Bucharest, pp: 245-248.

Petrescu, F. and R. Petrescu, 2005b. Contributions at the dynamics of cams. Proceedings of the 9th IFToMM International Symposium on Theory of Machines and Mechanisms, (TMM' 05), Bucharest, Romania, pp: 123-128.

Petrescu, F. and R. Petrescu, 2005c. Determining the dynamic efficiency of cams. Proceedings of the 9th IFToMM International Symposium on Theory of Machines and Mechanisms, (TMM' 05), Bucharest, Romania, pp: 129-134.

Petrescu, F. and R. Petrescu, 2005d. An original internal combustion engine. Proceedings of the 9th IFToMM International Symposium on Theory of Machines and Mechanisms, (TMM' 05), Bucharest, Romania, pp: 135-140.

Petrescu, F. and R. Petrescu, 2005e. Determining the mechanical efficiency of Otto engine's mechanism. Proceedings of the 9th IFToMM International Symposium on Theory of Machines and Mechanisms, (TMM 05), Bucharest, Romania, pp: 141-146.

Petrescu, F.I. and R.V. Petrescu, 2011. Mechanical Systems, Serial and Parallel (Romanian). 1st Edn., LULU Publisher, London, UK, pp: 124 
Petrescu, F.I. and R.V. Petrescu, 2012a. Kinematics of the planar quadrilateral mechanism. ENGEVISTA, 14: 345-348.

Petrescu, F.I. and R.V. Petrescu, 2012b. MecatronicaSisteme Seriale si Paralele. 1st Edn., Create Space Publisher, USA, pp: 128.

Petrescu, F.I. and R.V. Petrescu, 2013a. Cinematics of the 3R dyad. ENGEVISTA, 15: 118-124.

Petrescu, F.I. and R.V. Petrescu, 2013b. Forces and efficiency of cams. Int. Rev. Mechanical Eng.

Petrescu, F.I. and R.V. Petrescu, 2016a. Parallel moving mechanical systems kinematics. ENGEVISTA, 18: 455-491.

Petrescu, F.I. and R.V. Petrescu, 2016b. Direct and inverse kinematics to the anthropomorphic robots. ENGEVISTA, 18: 109-124.

Petrescu, F.I. and R.V. Petrescu, 2016c. Dynamic cinematic to a structure 2R. Revista Geintec-Gestao Inovacao E Tecnol., 6: 3143-3154.

Petrescu, R.V., R. Aversa, A. Apicella and F.I. Petrescu, 2016. Future medicine services robotics. Am. J. Eng. Applied Sci., 9: 1062-1087.

DOI: 10.3844/ajeassp.2016.1062.1087

Petrescu, F.I., B. Grecu, A. Comanescu and R.V. Petrescu, 2009. Some mechanical design elements. Proceeding of the International Conference on Computational Mechanics and Virtual Engineering, (MVE' 09), Braşov, pp: 520-525.

Petrescu, F.I., 2011. Teoria Mecanismelor si a Masinilor: Curs Si Aplicatii. 1st Edn., CreateSpace Independent Publishing Platform. ISBN-10: 1468015826. pp: 432.

Petrescu, F.I.T., 2015a. Geometrical synthesis of the distribution mechanisms. Am. J. Eng. Applied Sci., 8: 63-81. DOI: 10.3844/ajeassp.2015.63.81

Petrescu, F.I.T., 2015b. Machine motion equations at the internal combustion heat engines. Am. J. Eng. Applied Sci., 8: 127-137. DOI: 10.3844/ajeassp.2015.127.137

Petrescu, R.V., R. Aversa, B. Akash, R. Bucinell and J. Corchado et al., 2017a. Yield at thermal engines internal combustion. Am. J. Eng. Applied Sci., 10: 243-251. DOI: 10.3844/ajeassp.2017.243.251

Petrescu, R.V., R. Aversa, B. Akash, B. Ronald and J. Corchado et al., 2017b. Velocities and accelerations at the 3R mechatronic systems. Am. J. Eng. Applied Sci., 10: 252-263.

DOI: 10.3844/ajeassp.2017.252.263

Petrescu, R.V., R. Aversa, B. Akash, R. Bucinell and J. Corchado et al., 2017c. Anthropomorphic solid structures n-r kinematics. Am. J. Eng. Applied Sci., 10: 279-291. DOI: 10.3844/ajeassp.2017.279.291

Petrescu, R.V., R. Aversa, B. Akash, R. Bucinell and J. Corchado et al., 2017d. Inverse kinematics at the anthropomorphic robots, by a trigonometric method. Am. J. Eng. Applied Sci., 10: 394-411

DOI: 10.3844/ajeassp.2017.394.411
Petrescu, R.V., R. Aversa, B. Akash, R. Bucinell and J. Corchado et al., 2017e. Forces at internal combustion engines. Am. J. Eng. Applied Sci., 10: 382-393. DOI: 10.3844/ajeassp.2017.382.393

Petrescu, R.V., R. Aversa, B. Akash, R. Bucinell and J. Corchado et al., 2017f. Gears-Part I. Am. J. Eng. Applied Sci., 10: 457-472.

DOI: 10.3844/ajeassp.2017.457.472

Petrescu, R.V., R. Aversa, B. Akash, R. Bucinell and J. Corchado et al., 2017g. Gears-part II. Am. J. Eng. Applied Sci., 10: 473-483.

DOI: 10.3844/ajeassp.2017.473.483

Petrescu, R.V., R. Aversa, B. Akash, R. Bucinell and J. Corchado et al., 2017h. Cam-gears forces, velocities, powers and efficiency. Am. J. Eng. Applied Sci., 10: 491-505.

DOI: 10.3844/ajeassp.2017.491.505

Petrescu, R.V., R. Aversa, B. Akash, R. Bucinell and J. Corchado et al., 2017i. Dynamics of mechanisms with cams illustrated in the classical distribution. Am. J. Eng. Applied Sci., 10: 551-567. DOI: 10.3844/ajeassp.2017.551.567

Petrescu, R.V., R. Aversa, B. Akash, R. Bucinell and J. Corchado et al., 2017j. Testing by non-destructive control. Am. J. Eng. Applied Sci., 10: 568-583. DOI: 10.3844 /ajeassp.2017.568.583

Petrescu, R.V., R. Aversa, A. Apicella and F.I.T. Petrescu, 2017k. Transportation engineering. Am. J. Eng. Applied Sci., 10: 685-702. DOI: 10.3844 /ajeassp.2017.685.702

Petrescu, R.V., R. Aversa, S. Kozaitis, A. Apicella and F.I.T. Petrescu, 20171. The quality of transport and environmental protection, part I. Am. J. Eng. Applied Sci., 10: 738-755.

DOI: 10.3844/ajeassp.2017.738.755

Petrescu, R.V., R. Aversa, B. Akash, R. Bucinell and J. Corchado et al., $2017 \mathrm{~m}$. Modern propulsions for aerospace-a review. J. Aircraft Spacecraft Technol., 1: 1-8. DOI: 10.3844/jastsp.2017.1.8

Petrescu, R.V., R. Aversa, B. Akash, R. Bucinell and J. Corchado et al., 2017n. Modern propulsions for aerospace-part II. J. Aircraft Spacecraft Technol., 1: 9-17. DOI: $10.3844 /$ jastsp.2017.9.17

Petrescu, R.V., R. Aversa, B. Akash, R. Bucinell and J. Corchado et al., 2017o. History of aviation-a short review. J. Aircraft Spacecraft Technol., 1: 30-49. DOI: 10.3844 /jastsp.2017.30.49

Petrescu, R.V., R. Aversa, B. Akash, R. Bucinell and J. Corchado et al., 2017p. Lockheed martin-a short review. J. Aircraft Spacecraft Technol., 1: 50-68. DOI: 10.3844 /jastsp.2017.50.68

Petrescu, R.V., R. Aversa, B. Akash, J. Corchado and F. Berto et al., 2017q. Our universe. J. Aircraft Spacecraft Technol., 1: 69-79. DOI: 10.3844 jastsp.2017.69.79 
Petrescu, R.V., R. Aversa, B. Akash, J. Corchado and F. Berto et al., 2017r. What is a UFO? J. Aircraft Spacecraft Technol., 1: 80-90.

DOI: 10.3844 jastsp.2017.80.90

Petrescu, R.V., R. Aversa, B. Akash, J. Corchado and F. Berto et al., 2017s. About bell helicopter FCX-001 concept aircraft-a short review. J. Aircraft Spacecraft Technol., 1: 91-96.

DOI: 10.3844 /jastsp.2017.91.96

Petrescu, R.V., R. Aversa, B. Akash, J. Corchado and F. Berto et al., 2017t. Home at airbus. J. Aircraft Spacecraft Technol., 1: 97-118.

DOI: 10.3844 jastsp.2017.97.118

Petrescu, R.V., R. Aversa, B. Akash, J. Corchado and F. Berto et al., 2017u. Airlander. J. Aircraft Spacecraft Technol., 1: 119-148.

DOI: $10.3844 /$ jastsp.2017.119.148

Petrescu, R.V., R. Aversa, B. Akash, J. Corchado and F. Berto et al., 2017v. When boeing is dreaming-a review. J. Aircraft Spacecraft Technol., 1: 149-161. DOI: $10.3844 /$ jastsp.2017.149.161

Petrescu, R.V., R. Aversa, B. Akash, J. Corchado and F. Berto et al., 2017w. About Northrop Grumman. J. Aircraft Spacecraft Technol., 1: 162-185.

DOI: $10.3844 /$ jastsp.2017.162.185

Petrescu, R.V., R. Aversa, B. Akash, J. Corchado and F. Berto et al., 2017x. Some special aircraft. J. Aircraft Spacecraft Technol., 1: 186-203. DOI: $10.3844 /$ jastsp.2017.186.203

Petrescu, R.V., R. Aversa, B. Akash, J. Corchado and F. Berto et al., 2017y. About helicopters. J. Aircraft Spacecraft Technol., 1: 204-223. DOI: $10.3844 /$ jastsp.2017.204.223

Petrescu, R.V., R. Aversa, B. Akash, F. Berto and A. Apicella et al., 2017z. The modern flight. J. Aircraft Spacecraft Technol., 1: 224-233. DOI: $10.3844 /$ jastsp.2017.224.233

Petrescu, R.V., R. Aversa, B. Akash, F. Berto and A. Apicella et al., 2017aa. Sustainable energy for aerospace vessels. J. Aircraft Spacecraft Technol., 1: 234-240. DOI: 10.3844/jastsp.2017.234.240

Petrescu, R.V., R. Aversa, B. Akash, F. Berto and A. Apicella et al., 2017ab. Unmanned helicopters. J. Aircraft Spacecraft Technol., 1: 241-248. DOI: $10.3844 /$ jastsp.2017.241.248

Petrescu, R.V., R. Aversa, B. Akash, F. Berto and A. Apicella et al., 2017ac. Project HARP. J. Aircraft Spacecraft Technol., 1: 249-257. DOI: 10.3844 /jastsp.2017.249.257

Petrescu, R.V., R. Aversa, B. Akash, F. Berto and A. Apicella et al., 2017ad. Presentation of romanian engineers who contributed to the development of global aeronautics-part I. J. Aircraft Spacecraft Technol., 1: 258-271.

DOI: $10.3844 /$ jastsp.2017.258.271
Petrescu, R.V., R. Aversa, B. Akash, F. Berto and A. Apicella et al., 2017ae. A first-class ticket to the planet mars, please. J. Aircraft Spacecraft Technol., 1: 272-281. DOI: $10.3844 /$ jastsp.2017.272.281

Petrescu, R.V., R. Aversa, A. Apicella, M.M. Mirsayar and S. Kozaitis et al., 2018a. NASA started a propeller set on board voyager 1 after 37 years of break. Am. J. Eng. Applied Sci., 11: 66-77.

DOI: 10.3844 /ajeassp.2018.66.77

Petrescu, R.V., R. Aversa, A. Apicella, M.M. Mirsayar and S. Kozaitis et al., 2018b. There is life on mars? Am. J. Eng. Applied Sci., 11: 78-91. DOI: 10.3844/ajeassp.2018.78.91

Petrescu, R.V., R. Aversa, A. Apicella and F.I.T. Petrescu, 2018c. Friendly environmental transport. Am. J. Eng. Applied Sci., 11: 154-165. DOI: 10.3844/ajeassp.2018.154.165

Petrescu, R.V., R. Aversa, B. Akash, T.M. Abu-Lebdeh and A. Apicella et al., 2018d. Buses running on gas. Am. J. Eng. Applied Sci., 11: 186-201. DOI: 10.3844 /ajeassp.2018.186.201

Petrescu, R.V., R. Aversa, B. Akash, T.M. Abu-Lebdeh and A. Apicella et al., 2018e. Some aspects of the structure of planar mechanisms. Am. J. Eng. Applied Sci., 11: 245-259.

DOI: 10.3844/ajeassp.2018.245.259

Petrescu, RV., R. Aversa, T.M. Abu-Lebdeh, A. Apicella and F.I.T. Petrescu, 2018f. The forces of a simple carrier manipulator. Am. J. Eng. Applied Sci., 11: 260-272. DOI: 10.3844/ajeassp.2018.260.272

Petrescu, RV., R. Aversa, T.M. Abu-Lebdeh, A. Apicella and F.I.T. Petrescu, 2018g. The dynamics of the otto engine. Am. J. Eng. Applied Sci., 11: 273-287.

DOI: 10.3844/ajeassp.2018.273.287

Petrescu, RV., R. Aversa, T.M. Abu-Lebdeh, A. Apicella and F.I.T. Petrescu, 2018h. NASA satellites help us to quickly detect forest fires. Am. J. Eng. Applied Sci., 11: 288-296.

DOI: 10.3844 /ajeassp.2018.288.296

Petrescu, RV., R. Aversa, T.M. Abu-Lebdeh, A. Apicella and F.I.T. Petrescu, 2018i. Kinematics of a mechanism with a triad. Am. J. Eng. Applied Sci., 11: 297-308. DOI: 10.3844/ajeassp.2018.297.308

Petrescu, R.V., R. Aversa, A. Apicella and F.I.T. Petrescu, 2018j. Romanian engineering "on the wings of the wind". J. Aircraft Spacecraft Technol., 2: 1-18. DOI: $10.3844 /$ jastsp.2018.1.18

Petrescu, R.V., R. Aversa, A. Apicella and F.I.T. Petrescu, 2018k. NASA Data used to discover eighth planet circling distant star. J. Aircraft Spacecraft Technol., 2: 19-30.

DOI: 10.3844 jastsp.2018.19.30 
Petrescu, R.V., R. Aversa, A. Apicella and F.I.T. Petrescu, 20181. NASA has found the most distant black hole. J. Aircraft Spacecraft Technol., 2: 31-39. DOI: 10.3844 jastsp.2018.31.39

Petrescu, R.V., R. Aversa, A. Apicella and F.I.T. Petrescu, 2018m. Nasa selects concepts for a new mission to titan, the moon of saturn. J. Aircraft Spacecraft Technol., 2: 40-52. DOI: $10.3844 /$ jastsp.2018.40.52
Petrescu, R.V., R. Aversa, A. Apicella and F.I.T. Petrescu, 2018n. NASA sees first in 2018 the direct proof of ozone hole recovery. J. Aircraft Spacecraft Technol., 2: 53-64. DOI: 10.3844/jastsp.2018.53.64

\section{Source of Figures}

http://mastermssmm.blogspot.com/ 